\title{
Guide to Verification and Validation of the SCALE-4 Radiation Shielding Software
}

Prepared by

B. L. Broadhead, M. B. Emmett, J. S. Tang

Oak Ridge National Laboratory

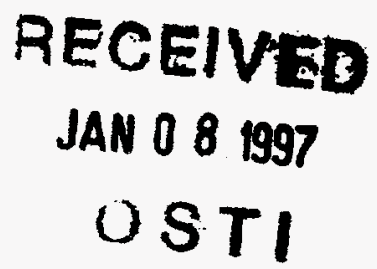

Prepared for

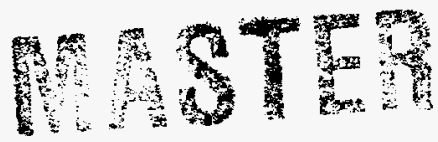

U.S. Nuclear Regulatory Commission

MSTRIDUTION OF THIS DOCUMENT IS UNLUATEO 


\section{AVAILABILITY NOTICE}

Availability of Reference Materials Cited in NRC Publications

Most documents cited in NRC publications will be availabie from one of the following sources:

1. The NRC Public Document Room, 2120 L Street, NW., Lower Level, Washington, DC 20555-0001

2. The Superintendent of Documents, U.S. Government Printing Office, P. O. Box 37082 , Washington, DC 20402-9328

3. The National Technical Information Service, Springfield, VA 22161-0002

Although the listing that follows represents the majority of documents cited in NRC publications, it is not intended to be exhaustive.

Referenced documents available for inspection and copying for a fee from the NRC Public Document Room include NRC correspondence and internal NRC memoranda: NRC bulletins, circulars, information notices. inspection and investigation notices: licensee event reports; vendor reports and correspondence: Commission papers; and applicant and licensee documents and correspondence.

The following documents in the NUREG series are available for purchase from the Government Printing Office: formal NRC staff and contractor reports, NRC-sponsored conference proceedings, international agreement reports, grantee reports, and NRC booklets and brochures. Also available are regulatory guides, NRC regulations in the Code of Federal Regulations, and Nuclear Regulatory Commission Issuances.

Documents avaflable from the National Technical Information Service include NUREG-series reports and technical reports prepared by other Federal agencies and reports prepared by the Atomic Energy Commission. forerunner agency to the Nuclear Regulatory Commission.

Documents available from public and special technical libraries include all open literature items, such as books, journal articles, and transactions. Federal Register notices. Federal and State legislation, and congressional reports can usuaily be obtained from these libraries.

Documents such as theses, dissertations. foreign reports and translations, and non-NRC conference proceedings are available for purchase from the organization sponsoring the publication cited.

Single copies of NRC draft reports are available free, to the extent of supply. upon written request to the Office of Administration, Distribution and Mail Services Section, U.S. Nuclear Regulatory Commission, Washington, DC 20555-0001.

Coples of industry codes and standards used in a substantive manner in the NRC regulatory process are maintained at the NRC Library. Two White Flint North. 11545 Rockville Pike. Rockville. MD 20852-2738. for use by the public. Codes and standards are usually copyrighted and may be purchased from the originating organization or, if they are American National Standards, from the American National Standards institute. 1430 Broadway, New York, NY 10018-3308.

\section{DISCLAIMER NOTICE}

This report was prepared as an account of work sponsored by an agency of the United States Government. Neither the United States Government nor any agency thereof, nor any of their employees, makes any warranty, expressed or implied, or assumes any legal liability or responsibility for any third party's use, or the results of such use, of any information, apparatus, product, or process disclosed in this report, or represents that its use by such third party would not infringe privately owned rights. 


\section{Guide to Verification and Validation of the SCALE-4 \\ Radiation Shielding Software}

Manuscript Completed: November 1996

Date Published: December 1996

Prepared by

B. L. Broadhead, M. B. Emmett, J. S. Tang

Oak Ridge National Laboratory

Managed by Lockheed Martin Energy Research Corporation

P.O. Box 2008

Oak Ridge, TN 37831-6370

Prepared for

Spent Fuel Project Office

Office of Nuclear Material Safety and Safeguards

U.S. Nuclear Regulatory Commission

Washington, DC 20555-0001

NRC Job Code B0009 


\section{DISCLAMMER}

Portions of this document may be illegible in electronic image products. Images are produced from the best available original document. 


\section{DISCLAIMER}

This report was prepared as an account of work sponsored by an agency of the United States Government. Neither the United States Government nor any agency thereof, nor any of their employees, make any warranty, express or implied, or assumes any legal liability or responsibility for the accuracy, completeness, or usefulness of any information, apparatus, product, or process disclosed, or represents that its use would not infringe privately owned rights. Reference herein to any specific commercial product, process, or service by trade name, trademark, manufacturer, or otherwise does not necessarily constitute or imply its endorsement, recommendation, or favoring by the United States Government or any agency thereof. The views and opinions of authors expressed herein do not necessarily state or reflect those of the United States Government or any agency thereof. 


\begin{abstract}
Whenever a decision is made to newly install the SCALE radiation shielding software on a computer system, the user should run a set of verification and validation $(V \& V)$ test cases to demonstrate that the software is properly installed and functioning correctly. This report is intended to serve as a guide for this V\&V in that it specifies test cases to run and gives expected results. The report describes the V\&V that has been performed for the radiation shielding software in a version of SCALE- $4 .{ }^{1}$

This report provides documentation of sample problems which are recommended for use in the V\&V of the SCALE-4 system for all releases. The results reported in this document are from the SCALE-4.2P version which was run on an IBM RS/6000 workstation. These results verify that the SCALE-4 radiation shielding software has been correctly installed and is functioning properly. A set of problems for use by other shielding codes (e.g., MCNP, ${ }^{2}$ TWOTRAN, ${ }^{3}$ $\mathrm{MORSE}^{4-6}$ ) performing similar V\&V are discussed.

A validation has been performed for XSDRNPM ${ }^{7}$ and MORSE-SGC ${ }^{6}$ utilizing $\mathrm{SAS}^{8}$ and $\mathrm{SAS} 4^{9}$ shielding sequences and the SCALE 27-18 group (27N-18COUPLE) cross-section library for typical nuclear reactor spent fuel sources and a variety of transport package geometries. The experimental models used for the validation were taken from two previous applications of the SASI and SAS4 methods.
\end{abstract}





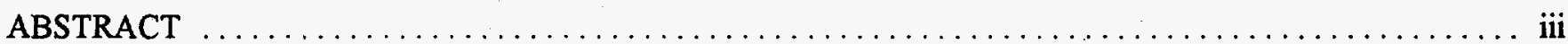

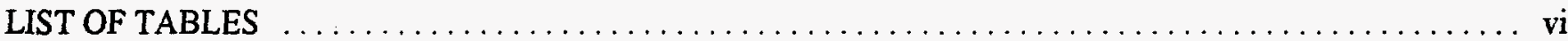

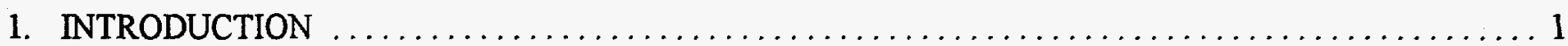

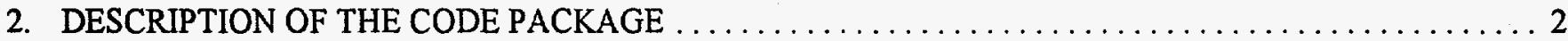

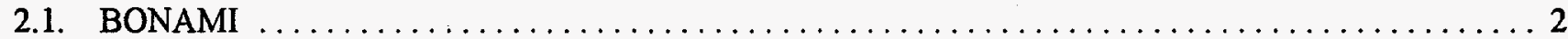

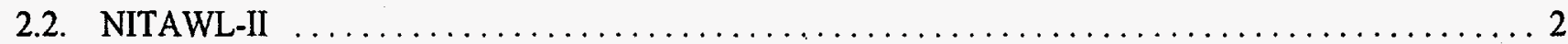

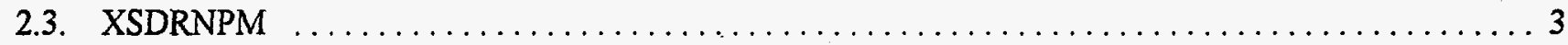

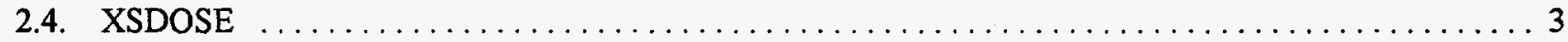

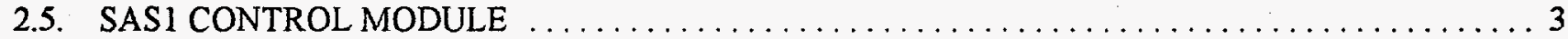

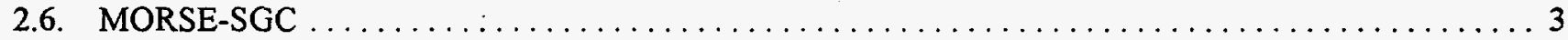

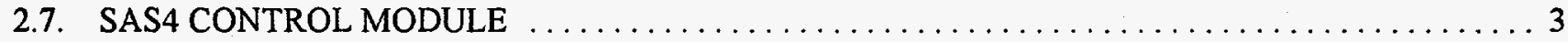

2.8. THE 27-NEUTRON 18 -GAMMA CROSS-SECTION LIBRARY $\ldots \ldots \ldots \ldots \ldots \ldots \ldots \ldots \ldots 4$

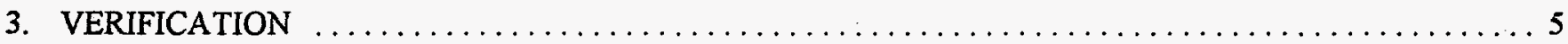

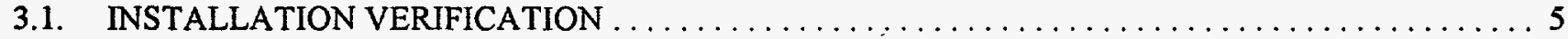

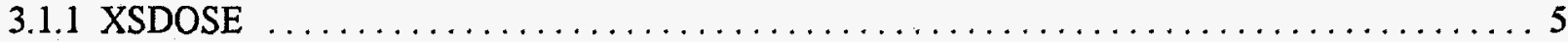

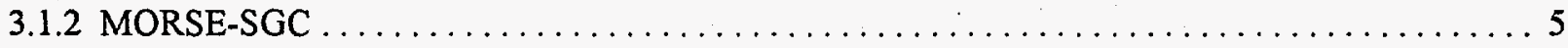

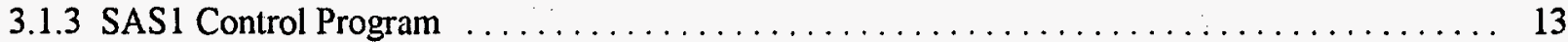

3.1.4 SAS4 Control Program $\ldots \ldots \ldots \ldots \ldots \ldots \ldots \ldots \ldots \ldots \ldots \ldots \ldots \ldots \ldots \ldots, 13$

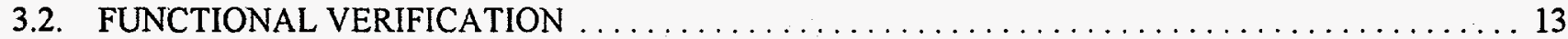

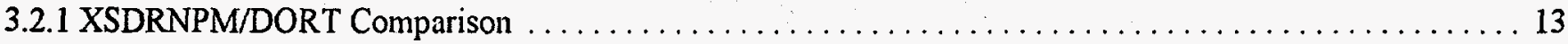

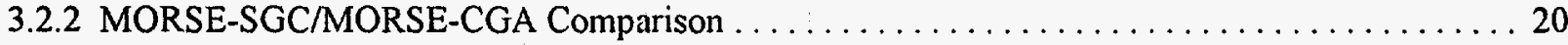

3.2.3 SAS1/SAS4 Comparison ......................................... 20

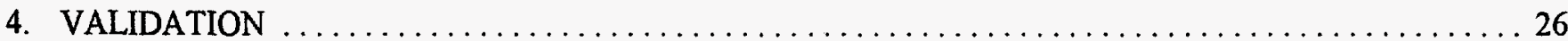

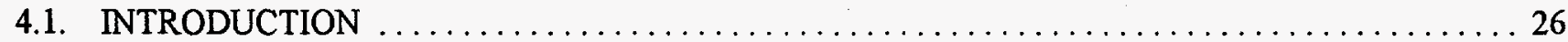

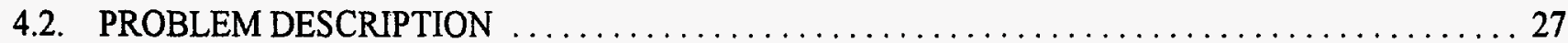

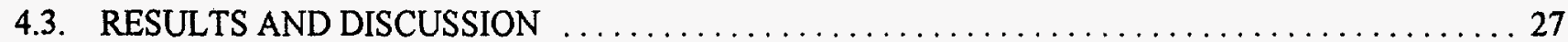

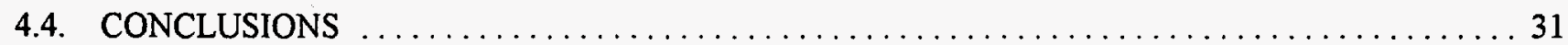

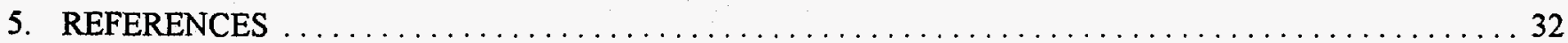

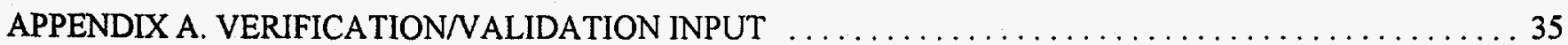

APPENDIX B. UTILITY CODE LISTINGS . . . . . . . . . . . . . . . . . . . . . . . . . . . . . 39 


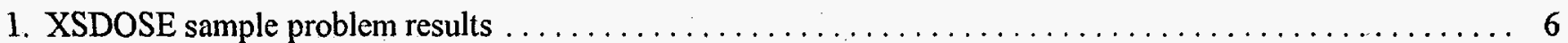

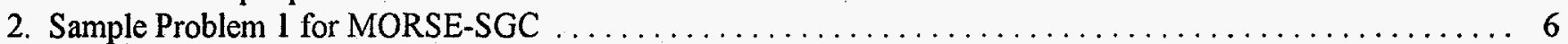

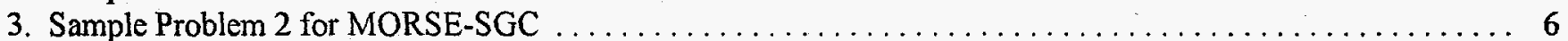

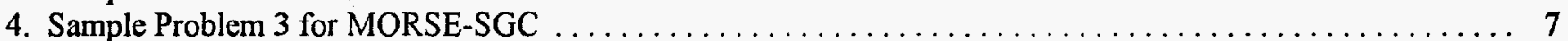

5. Sample Problem 4 for MORSE-SGC $\ldots \ldots \ldots \ldots \ldots \ldots \ldots \ldots \ldots \ldots \ldots \ldots \ldots \ldots \ldots \ldots \ldots \ldots, \ldots \ldots \ldots$

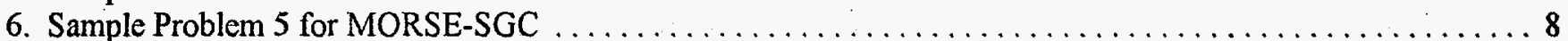

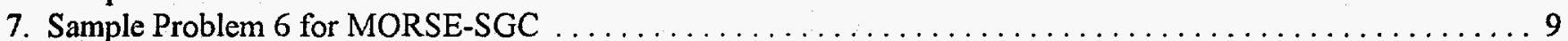

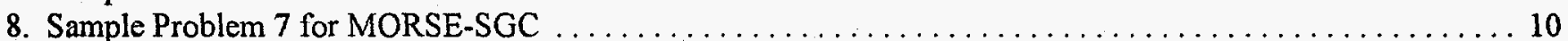

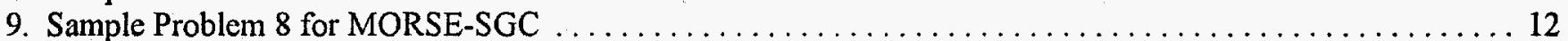

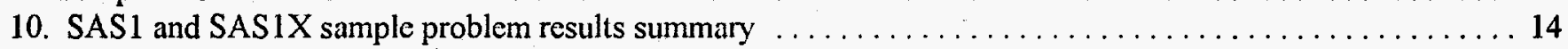

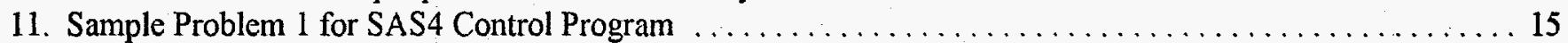

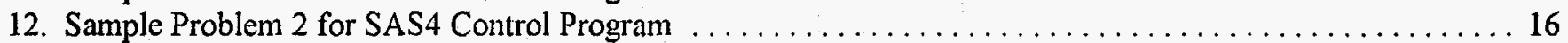

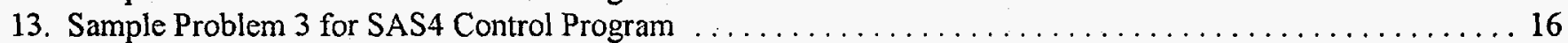

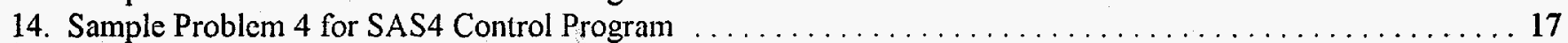

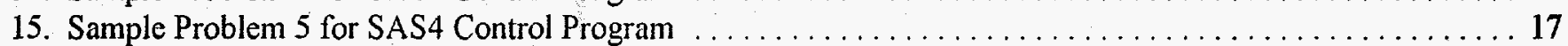

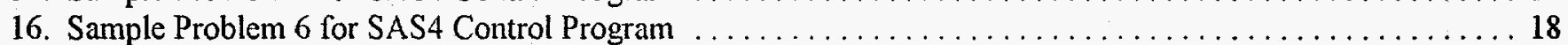

17. Sample Problem 7 for SAS4 Control Program $\ldots \ldots \ldots \ldots \ldots \ldots \ldots \ldots \ldots \ldots \ldots \ldots \ldots \ldots \ldots \ldots \ldots$

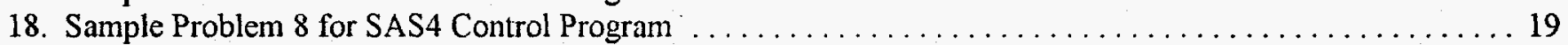

19. Dose rates $(\mathrm{mrem} / \mathrm{h})$ of OECD problem la calculated by XSDRNPM and DORT $\ldots \ldots \ldots \ldots \ldots \ldots$

20. Comparison of MORSE-SGC and MORSE-CGA results for sample problem $4 \ldots \ldots \ldots \ldots \ldots \ldots \ldots 21$

21. Comparison of MORSE-SGC and MORSE-CGA results for sample problem $5 \ldots \ldots \ldots \ldots \ldots \ldots \ldots 22$

22. Comparison of MORSE-SGC and MORSE-CGA results for sample problem $6 \ldots \ldots \ldots \ldots \ldots \ldots \ldots 23$

23. Comparison of MORSE-SGC and MORSE-CGA results for sample problem $7 \ldots \ldots \ldots \ldots \ldots \ldots \ldots$

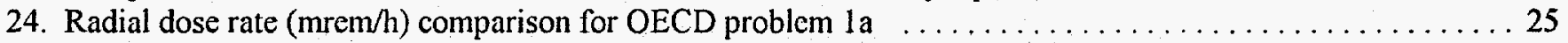

25. Comparison of measured and calculated neutron dose rates for graphite slabs $\ldots \ldots \ldots \ldots \ldots \ldots \ldots 28$

26. Comparison of measured and calculated neutron dose rates for iron slabs $\ldots \ldots \ldots \ldots \ldots \ldots \ldots \ldots \ldots$

27. Comparison of measured and calculated neutron dose rates for polycthylene slabs $\ldots \ldots \ldots \ldots \ldots \ldots . .29$

28. Comparison of measured and calculated photon dose rates for iron slabs $\ldots \ldots \ldots \ldots \ldots \ldots \ldots \ldots . \ldots 29$

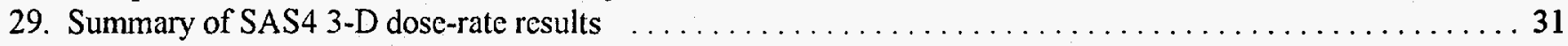

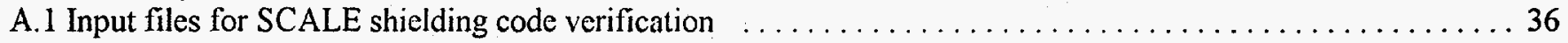

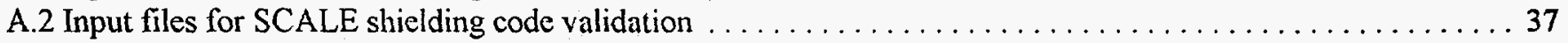




\section{INTRODUCTION}

The purpose of this report is to present a guide on verification and validation (V\&V) of the SCALE-4 radiation shielding software with the validation emphasis on spent fuel cask shielding. This report serves as documentation of the problems used in the V\&V of the SCALE-4 system for all releases. The verification problems specified by code developers have been run, and the results compare well with those in the SCALE- 4.2 baseline. ${ }^{10}$ The SCALE V\&V plan $^{11}$ describes the methods used for the baseline V\&V.

Although there are many definitions of software V\&V, the SCALE configuration management plan, SCALE-CMP-001, ${ }^{12}$ specifies the following:

Verification: Assurance that a computer code correctly performs the operations specified in a numerical model. This is usually accomplished by comparing results to a hand calculation or an analytical solution or approximation.

Validation: Assurance that a model as embodied in a computer code is a correct representation of the process or system for which it is intended. This is usually accomplished by comparing code results to either physical data or a validated code designed to perform the same type of analysis.

These definitions apply in this document.

Verification and validation can be very similar in that both are exercising a code with input for which there is a known result. In some cases the same known system may be used in both the V\&V. Verification and validation are different, however, because the end use of the results is different. Verification is intended to demonstrate that the software has been properly coded, installed on a computer, and performs the intended functions for a given set of input. Results of the verification are compared against documented results as specified in the verification plan. Validation is the process of demonstrating that the software predicts "correct" results for the "systems for which it is intended." The calculated results for systems with a known solution are used to establish the calculational bias. The establishment of the bias defines a range over which the result is acceptably correct. Experimental parameters and physical properties of these systems are used to determine the range of applicability of the validation and define the systems for which the bias applies.

In Sect. 2, the computer codes and data are briefly described; in Sect. 3, the results of the shielding code verification are presented; in Sect. 4, validation results are presented. The vcrification results in Sect. 3 have been subdivided into two categories. The first category is the installation verification. The results for the sample problems distributed with SCALE for each module are presented. These problems exercise many of the input options of the codes and are intended to demonstrate that the codes have been properly installed on the computer, are executing properly, and are properly interfacing with the system hardware configuration. The scripts used to execute the codes are also being tested during this phase. The installation verification represents a minimum set of problems that must be run each time the code is newly installed on a computer system. The second verification category is the functional verification. In this phase; the functionality of the codes is being tested. The codes are used to solve analytic problems for which the results are known. An intercode comparison between several shielding codes is also presented.

The validation presented in Sect. 4 is comprised of the analysis of several cask dose-rate experiments using both the SAS1 and SAS4 radiation shielding sequences. The validation experiments cover a fairly broad range of spent fuel burnups and two different cask matcrial types. The SCALE 27N-18COUPLE ENDF/B-IV cross-section library was utilized throughout this work. 


\section{DESCRIPTION OF THE CODE PACKAGE}

The following subsections give a brief description of the program modules which were verified and validated. Each module in SCALE has a version number which is updated whenever the code is revised. This version number is printed when the module is executed and is also indicated in the documentation distributed with each release. The version numbers of the program modules should be checked when calculations are performed to verify that the correct versions are being used. When a code version changes, the nature of the modifications should be reviewed and cases run should be checked to see if complete verification and/or validation is warranted.

\subsection{BONAMI}

BONAMI $^{13}$ performs resonance shielding through the application of the Bondarenko shielding factor method. BONAMI reads an AMPX ${ }^{14}$ master format cross-section library and applies Bondarenko corrections to all nuclides that have Bondarenko data. Input to BONAMI, provided by the SAS1 and SAS4 control sequences, includes information relating to the physical characteristics (composition of material, size, geometry, temperature) of the system being calculated. BONAMI produces a Bondarenko-corrected master format library which is read by NITAWL-II. ${ }^{15}$ For SCALE libraries, the Bondarenko technique is used primarily to process unresolved region resonance data and to process resonance nuclides which were not prepared by XLACS ${ }^{16}$ (such as the SCALE 16-group Hansen-Roach library or ENDF/B-VI nuclides processed with $\mathrm{NJOY}^{17}$ ). For the $27 \mathrm{~N}-18 \mathrm{COUPLE}$ master crosssection library used in this validation, the primary purpose of the BONAMI functional module is to select the required material cross sections and to create a problem-dependent AMPX master cross-section library to be processed by NITAWL-II. No data processing is performed in BONAMI for the $27 \mathrm{~N}-18$ COUPLE cross-section library.

\subsection{NITAWL-II}

NITAWL-II applies the Nordheim Integral Treatment to perform neutron cross-section processing in the resolved resonance range for nuclides that have ENDF/B resonance parameter data. This technique involves the numerical integration of ENDF/B resonance parameters using a calculated flux distribution which is based on the collision density across each resonance and subsequent weighting of the cross section to the desired broad group structure. Input data to NITAWL-II, automatically provided by the SAS1 and SAS4 control sequences, include information relating to the physical and neutronic characteristics of the system being calculated. NITAWL-II uses these data to complete the processing of the problem-dependent master library from BONAMI. NITAWL-II assembles the groupto-group transfer arrays from the elastic and inelastic scattering components and performs other tasks to produce a problem-dependent AMPX working format cross-section library which can be used by XSDRNPM and MORSESGC. The analyst specifies the resonance parameters based on the available options. The options include (1) a homogeneous medium treatment which treats the resonance region of the fissile mixture as if it were an infinite homogeneous media and (2) a finite lump treatment which treats the resonance region as if the fissile mixture were a discrete lump with a $\mathrm{l} / \mathrm{E}$ return flux at the boundary. This latter option is for problems where the system is substantially heterogeneous or where reflector effects are important. These options are automatically invoked in the SAS1 and SAS4 control sequences according to the keywords INFHOMMEDIUM, LATTICECELL, or MULTIREGION. The INFHOMMEDIUM option treats the various mixtures as an infinite homogeneous media. The LATTICECELL option utilizes an infinite lattice of repeated cells for the resonance self-shielding correction. With the MULTIREGION option, a single-cell resonance self-shielding calculation is made. 


\subsection{XSDRNPM}

XSDRNPM is a general-purpose, one-dimensional (1-D), discrete-ordinates code used for several purposes in SCALE. In the SASIX and SAS1 shielding sequences, XSDRNPM is used to solve the 1-D Boltzmann equation in slab, cylindrical, or spherical geometry. In the SAS4 shielding sequence XSDRNPM is used in the adjoint mode to produce 1-D importance fluxes which the control sequence then uses to generate automated biases for MORSE-SGC. As part of the SAS1X and SAS4 sequences, XSDRNPM is optionally used to solve the 1-D Boltzmann equation for a specified fissile system and then to produce spatially averaged cross sections for subsequent use in an XSDRNPM or MORSE-SGC calculation.

\subsection{XSDOSE}

XSDOSE is a computer program used in conjunction with XSDRNPM to compute the flux and the resulting dose at various points outside a finite cylinder or sphere. XSDOSE can also compute the flux and/or dose at various points due to a finite rectangular surface source or a circular disc. The code assumes that the outgoing angular flux distribution on the rectangle, cylinder, sphere, or disc is independent of position and that the surrounding media is a void. The numerical technique used in XSDOSE is suitable for points on, close to, or far away from the source.

\subsection{SAS1 CONTROL MODULE}

The SAS1 control module invokes the control sequences, SAS1 and SAS1X. These control sequences serve similar functions in that they read user-spccificd data, which includes the required cross-section library, specifications for mixtures, information for resonance region cross-section processing of nuclides (size, geometry, and temperature), and geometry models for XSDRNPM, and then prepare the input for the various functional modules, depending on which sequence is specified. Physical and neutronics information (such as theoretical density, molecular weights, average resonance region background cross sections, etc.) not supplied explicitly but required by the functional modules is supplied by the Standard Composition Library ${ }^{18}$ or calculated by the Materials Information Processor. ${ }^{19}$ The SAS1 and SAS4 control sequences were primarily used in the validation presented in Sect. 4. The SAS1 control sequence prepares the input for BONAMI, NITAWL-II, XSDRNPM, and XSDOSE. ${ }^{20}$

\subsection{MORSE-SGC}

MORSE-SGC is a three-dimensional (3-D) multipurpose neutron and gamma-ray transport Monte Carlo code which is part of the SAS4 control sequence and also a stand-alone code in SCALE. The 3-D MARS geometry package used in MORSE allows modeling complicated structures such as spent fuel shipping casks. MORSE-SGC solves the 3-D Boltzmann equation in either forward or adjoint mode using multigroup cross-section libraries. A number of biasing options are available in MORSE-SGC; and when running MORSE-SGC as part of SAS4, the biasing parameters are provided by data from an adjoint XSDRNPM calculation.

\subsection{SAS4 CONTROL MODULE}

The SAS4 control module includes only a single control sequence, SAS4. This control sequence reads user-specified data, which include the required cross-section library, specifications for mixtures, information for resonance region cross-section processing of nuclides (size, geometry, and temperature), and geometry models for XSDRNPM and MORSE-SGC, and then prepares the input for the various functional modules, depending on which sequence is 
Description

specified. Additional physical and neutronics information is supplied by the Standard Composition Library or calculated by the Materials Information Processor. The SAS1 and SAS4 control sequences were primarily used in the validation presented in Sect. 4. The SAS4 control sequence prepares the input for BONAMI, NITAWL-II, XSDRNPM, and MORSE-SGC.

\subsection{THE 27-NEUTRON 18-GAMMA CROSS-SECTION LIBRARY}

The 27 neutron-18 gamma group ENDF/B-IV AMPX master cross-section library in SCALE is activated in the SAS1 and SAS4 control sequences by specifying $27 \mathrm{~N}-18 \mathrm{COUPLE}$ as the cross-section library name. The 27-group neutron library is the broad-group companion library to the 218-group Criticality Safety Reference Library. The Criticality Safety Reference Library master library, which is based on ENDF/B-IV data, was generated as a pseudo problemindependent fine-group structure library for use in general criticality safety analysis and shipping cask calculations. The 27-group library was collapsed from the 218-group library using a fission-(1/Eo)-Maxwellian spectrum on a nuclide-by-nuclide basis. Explicit ENDF/B-IV resonance parameters are carried for resonance nuclides in both the 27- and 218-group master libraries. These resonance parameters are used by the NITAWL-II functional module in the CSAS, ${ }^{21}$ SAS1, and SAS4 control modules for calculating problem-dependent, self-shielded resonance region cross sections. The 18-group gamma library was generated directly from ENDF/B-IV data before being coupled with the 27-group neutron library.

The 27N-18COUPLE AMPX master format cross-section library was originally created in August 1981. With the release of SCALE-4.0, the original 27-group library was processed into the new AMPX master library format using CORECTOL. ${ }^{22}$ In addition, all the nuclides were processed with PERFUME, ${ }^{22}$ which adjusts moments to physically reasonable values. The cross sections distributed with versions of SCALE 4.0 or later are not compatible with previous versions of SCALE. 


\section{VERIFICATION}

The purpose of this section is to present code verification results. Verification is accomplished by running the verification problems specified in the SCALE V\&V plan and demonstrating that the codes perform consistently with the SCALE-4.2 baseline results. The verification has been subdivided into two categories: installation verification and functional verification. The installation verification input and output files are distributed along with the SCALE code package. Appendix A describes input files which are available (see the SCALE homepage on the World Wide Web (WWW) which can be accessed from http://www.cad.ornl.gov).

Included in Appendix B of Ref. 23 is a copy of the submit $4.2 p$ script which was used to execute the V\&V problems. The scale4 script, which it references, is included in the SCALE distribution.

Included in Appendix B of this document is a listing of READX, a FORTRAN program which is used to collect the results from XSDRNPM, XSDOSE, and/or SASI calculations. Upon execution the user is prompted for the names of an index of the output files to be searched and the name of the output file to store the results. READX searches strings in the output and collects XSDRNPM and/or XSDOSE results.

\subsection{INSTALLATION VERIFICATION}

Installation verification consisted of running the sample problems normally distributed with the modules in the SCALE package and demonstrating that the results were consistent with those in the SCALE- 4.2 baseline. The sample problems represent a minimum set of calculations which should be run when the codes are installed on a computer system.

Reference 23 contains results from the BONAMI, NITAWL-II, and XSDRNPM sample problems. The others are discussed in the following sections.

\subsubsection{XSDOSE}

XSDOSE sample problem results are presented in Table 1. Table 1 was generated using the FORTRAN utility code READX. The format of the output from READX consists of the results file name followed by a list of the output files scanned. If a string is identified as being from XSDRNPM, the first 20 characters of the title are printed followed by selected output from the module. The value of "lambda" from XSDRNPM is printed, if found, as is the message that the outer iteration limit was exceeded. Following the XSDRNPM results listing, the results from XSDOSE are listed. The format of the READX output gives the detector number followed by the neutron and gamma dose rates for each detector. A lambda of exactly 1.0000 generally means that the XSDRNPM problem was executed in the "fixed source" mode rather than in the "k-eff" mode. The results from each module are not identical but are consistent with the results presented in the SCALE- 4.2 baseline. The results presented in Table 1 verify that XSDOSE is correctly installed.

\subsubsection{MORSE-SGC}

The MORSE-SGC sample problem results for eight sample problems are given in Tables 2 through 9. Monte Carlo calculations such as those performed in MORSE-SGC are particularly sensitive to changes in the random number sequence. Minor cross-section differences and differences in the random number generator between two different computers may lead to seemingly large changes in the results. The deviation of the results must be taken into consideration when comparing the code performance between different computer systems. The MORSE-SGC results are consistent with those presented in the SCALE-4.2 baseline. The results presented in Tables 2 through 9 verify that MORSE-SGC is correctly installed. 
Verification

Table 1. XSDOSE sample problem results

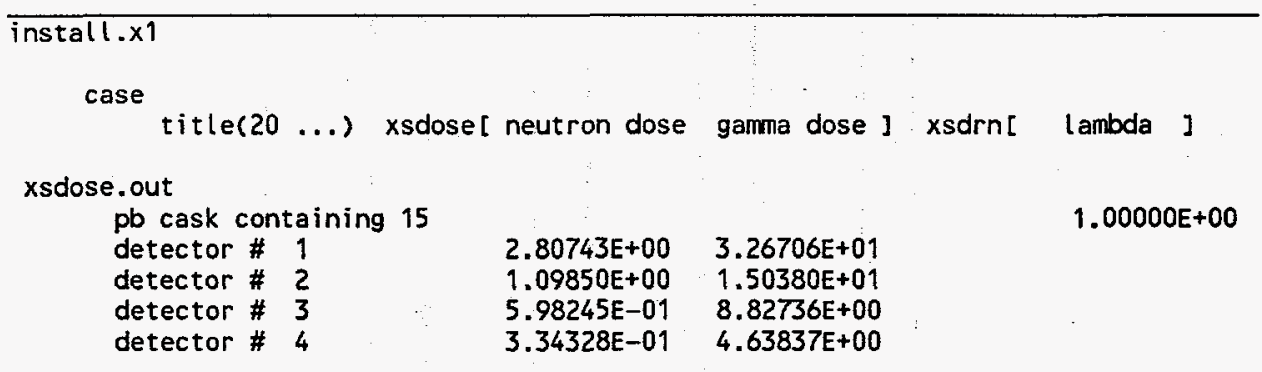

Table 2. Sample Problem 1 for MORSE-SGC

\begin{tabular}{|c|c|c|c|c|}
\hline detector & $\begin{array}{l}\text { uncoll } \\
\text { response } \\
0.0000 E+00 \\
0.0000 E+00\end{array}$ & $\begin{array}{l}\text { fsd } \\
\text { uncoll } \\
.00000 \\
.00000\end{array}$ & $\begin{array}{l}\text { total } \\
\text { response } \\
2.6085 \mathrm{E}-02^{\circ} \\
1.2185 \mathrm{E}-01\end{array}$ & $\begin{array}{l}\text { fsd } \\
\text { total } \\
.03735 \\
.03722\end{array}$ \\
\hline \multicolumn{2}{|c|}{$\begin{array}{l}\text { neutron deaths } \\
\text { killed by russian roulette } \\
\text { escaped } \\
\text { reached energy cutoff } \\
\text { reached time cutoff }\end{array}$} & $\begin{array}{r}\text { number } \\
13041 \\
17108 \\
0 \\
0\end{array}$ & $\begin{array}{c}\text { weight } \\
.44505 E+04 \\
.12070 E+05 \\
.00000 E+00 \\
.00000 E+00\end{array}$ & \\
\hline $\begin{array}{l}\text { number of } \\
\text { medium } \\
1 \\
2 \\
3\end{array}$ & $\begin{array}{l}\text { number } \\
374266 \\
217580 \\
576359\end{array}$ & & & \\
\hline
\end{tabular}

${ }^{a}$ Neutrons/source neutron (upper axial leakage).

Table 3. Sample Problem 2 for MORSE-SGC

\begin{tabular}{|c|c|c|c|c|c|}
\hline $\begin{array}{c}\text { detector } \\
1 \\
2\end{array}$ & $\begin{array}{c}\text { uncoll } \\
\text { response } \\
0.0000 \mathrm{E}+00 \\
0.0000 \mathrm{E}+00\end{array}$ & & $\begin{array}{l}\text { fsd } \\
\text { uncoll } \\
.00000 \\
.00000\end{array}$ & $\begin{array}{l}\text { total } \\
\text { response } \\
2.6613 \mathrm{E}-02^{\circ} \\
1.3410 \mathrm{E}-01\end{array}$ & $\begin{array}{c}\text { fsd } \\
\text { total } \\
.03804 \\
.03649\end{array}$ \\
\hline \multicolumn{2}{|c|}{$\begin{array}{l}\text { neuutron deaths } \\
\text { killed by russian roulette } \\
\text { escaped } \\
\text { reached energy cutoff } \\
\text { reached time cutoff }\end{array}$} & $\begin{array}{r}\text { number } \\
14275 \\
15978 \\
0 \\
0\end{array}$ & & $\begin{array}{c}\text { weight } \\
.47119 E+04 \\
.12035 E+05 \\
.00000 E+00 \\
.00000 E+00\end{array}$ & \\
\hline $\begin{array}{l}\text { number o } \\
\text { medium } \\
1 \\
2 \\
3\end{array}$ & $\begin{array}{l}\text { ing } \\
\text { number } \\
347450 \\
196900 \\
524253\end{array}$ & & & & \\
\hline
\end{tabular}

${ }^{8}$ Neutrons/source neutron. 
Table 4. Sample Problem 3 for MORSE-SGC

\begin{tabular}{|c|c|c|c|c|}
\hline $\begin{array}{c}\text { detector } \\
1 \\
2\end{array}$ & $\begin{array}{c}\text { uncoll } \\
\text { response } \\
0.0000 E+00 \\
0.0000 E+00\end{array}$ & $\begin{array}{c}\text { fsd } \\
\text { uncoll } \\
.00000 \\
.00000\end{array}$ & $\begin{array}{c}\text { total } \\
\text { response } \\
2.5338 E-02^{a} \\
7.4350 E-02\end{array}$ & $\begin{array}{c}\text { fsd } \\
\text { total } \\
.04462 \\
.04235\end{array}$ \\
\hline \multicolumn{2}{|c|}{$\begin{array}{l}\text { neutron deaths } \\
\text { killed by russian roulette } \\
\text { escaped } \\
\text { reached energy cutoff } \\
\text { reached time cutoff }\end{array}$} & $\begin{array}{r}\text { number } \\
19423 \\
9577 \\
0 \\
0\end{array}$ & $\begin{array}{c}\text { weight } \\
.14790 E+05 \\
.12036 E+05 \\
.00000 E+00 \\
.00000 E+00\end{array}$ & \\
\hline $\begin{array}{l}\text { number of } \\
\text { medium } \\
1 \\
2 \\
3\end{array}$ & $\begin{array}{l}\text { ng } \\
\text { number } \\
220109 \\
91026 \\
266583\end{array}$ & & & \\
\hline
\end{tabular}

"Neutrons/source neutron.

Table 5. Sample Problem 4 for MORSE-SGC

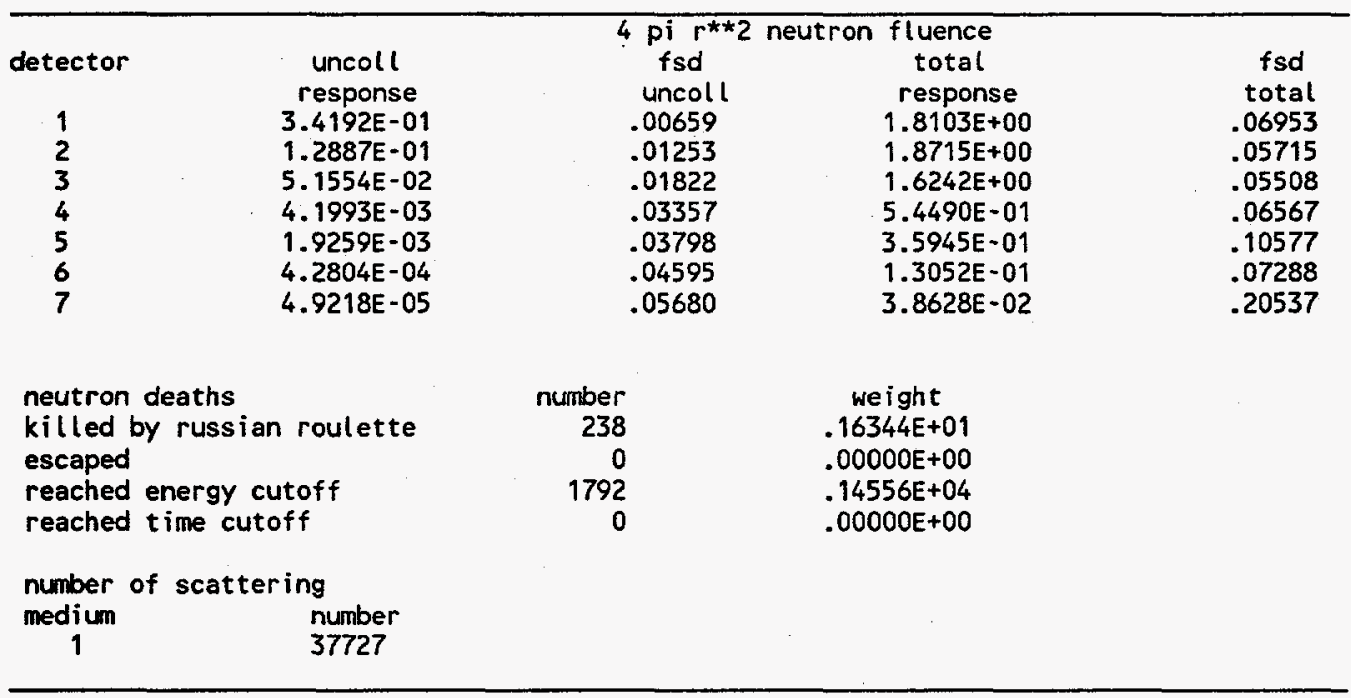


Verification

Table 6. Sample Problem 5 for MORSE-SGC

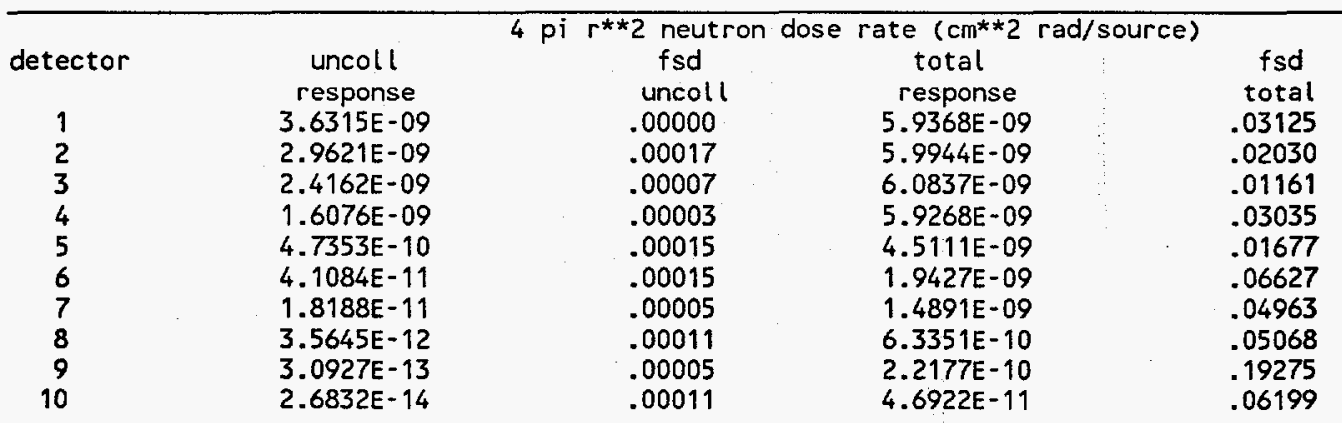

4 pi $r^{* * 2}$ gamma dose rate

responses(detector) ( $\mathrm{cm}{ }^{\star * 2} \mathrm{rad} /$ source)

detector

$\begin{array}{rc}1 & \text { response } \\ 2 & 0.0000 E+00 \\ 3 & 0.0000 E+00 \\ 4 & 0.0000 E+00 \\ 5 & 0.0000 E+00 \\ 6 & 0.0000 E+00 \\ 7 & 0.0000 E+00 \\ 8 & 0.0000 E+00 \\ 9 & 0.0000 E+00 \\ 10 & 0.0000 E+00\end{array}$

neutron deaths

killed by russian roulette escaped

reached energy cutoff

reached time cutoff

number of scattering medium

1

fsd
uncoll
.00000
.00000
.00000
.00000
.00000
.00000
.00000
.00000
.00000
.00000

number

5472

0
2534

0

$$
\begin{gathered}
\text { total } \\
\text { response } \\
5.8971 E-10 \\
8.0956 E-10 \\
9.9445 E-10 \\
1.1589 E-09 \\
1.1439 E-09 \\
6.4773 E-10 \\
4.9373 E-10 \\
2.7453 E-10 \\
1.1823 E-10 \\
4.9335 E-11
\end{gathered}
$$

weight

$.49019 E+01$

$.00000 E+00$

$.52371 E+04$

$.00000 E+00$ fsd

total

.07463

.05328

.04316

.02569

.02597

.02692

.03021

.03264

.06700

.08268 
Table 7. Sample Problem 6 for MORSE-SGC

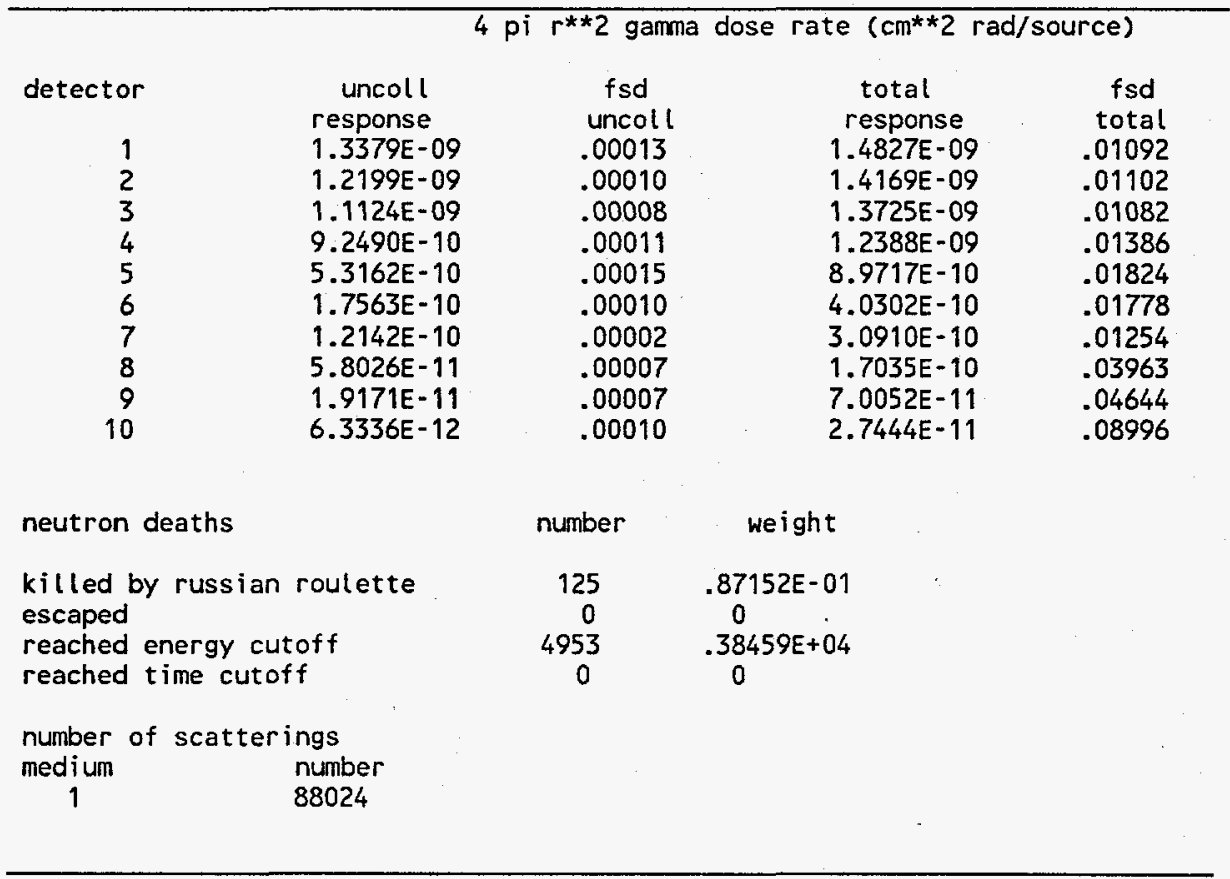


Verification

Table 8. Sample Problem 7 for MORSE-SGC

\begin{tabular}{|c|c|c|c|c|}
\hline \multirow[b]{2}{*}{$\begin{array}{c}\text { detector } \\
\qquad \begin{array}{c}1 \\
2 \\
3 \\
4 \\
5 \\
6 \\
7 \\
8 \\
9 \\
10 \\
11 \\
12 \\
13 \\
14\end{array}\end{array}$} & \multicolumn{4}{|c|}{4 pi r**2 group 1 fluence (neutrons/source) } \\
\hline & $\begin{array}{c}\text { uncoll } \\
\text { response } \\
2.9455 E-01 \\
8.6761 E-02 \\
2.5556 E-02 \\
2.2172 E-03 \\
6.5310 E-04 \\
0.0000 E+00 \\
0.0000 E+00 \\
0.0000 E+00 \\
0.0000 E+00 \\
0.0000 E+00 \\
0.0000 E+00 \\
0.0000 E+00 \\
0.0000 E+00 \\
0.0000 E+00\end{array}$ & $\begin{array}{l}f s d \\
\text { uncoll } \\
.00013 \\
.00012 \\
.00017 \\
.00013 \\
.00004 \\
.00000 \\
.00000 \\
.00000 \\
.00000 \\
.00000 \\
.00000 \\
.00000 \\
.00000 \\
.00000\end{array}$ & $\begin{array}{c}\text { total } \\
\text { response } \\
4.3651 \mathrm{E}-01 \\
1.8651 \mathrm{E}-01 \\
7.7176 \mathrm{E}-02 \\
1.2450 \mathrm{E}-02 \\
5.9234 \mathrm{E}-03 \\
6.8513 \mathrm{E}-01 \\
4.2041 \mathrm{E}-01 \\
1.7185 \mathrm{E}-01 \\
7.1174 \mathrm{E}-02 \\
3.3579 \mathrm{E}-02 \\
1.1566 \mathrm{E}-02 \\
4.6456 \mathrm{E}-03 \\
2.4127 \mathrm{E}-03 \\
5.2260 \mathrm{E}-04\end{array}$ & 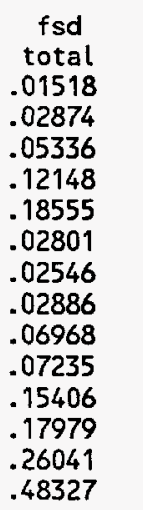 \\
\hline \multicolumn{5}{|c|}{$\begin{array}{l}4 \text { pi } r^{* * 2} \text { group } 10+11 \text { fluence (neutrons/source) } \\
\text { responses(detector) sambo for } 10 \text { region air }\end{array}$} \\
\hline $\begin{array}{r}1 \\
2 \\
3 \\
4 \\
5 \\
6 \\
7 \\
8 \\
9 \\
10 \\
11 \\
12 \\
13 \\
14\end{array}$ & $\begin{array}{c}\text { uncoll } \\
\text { response } \\
0.0000 E+00 \\
0.0000 E+00 \\
0.0000 E+00 \\
0.0000 E+00 \\
0.0000 E+00 \\
0.0000 E+00 \\
0.0000 E+00 \\
0.0000 E+00 \\
0.0000 E+00 \\
0.0000 E+00 \\
0.0000 E+00 \\
0.0000 E+00 \\
0.0000 E+00 \\
0.0000 E+00\end{array}$ & $\begin{array}{c}f s d \\
\text { uncoll } \\
.00000 \\
.00000 \\
.00000 \\
.00000 \\
.00000 \\
.00000 \\
.00000 \\
.00000 \\
.00000 \\
.00000 \\
.00000 \\
.00000 \\
.00000 \\
.00000\end{array}$ & $\begin{array}{c}\text { total } \\
\text { response } \\
1.9688 E-01 \\
1.9933 E-01 \\
1.7853 E-01 \\
7.8431 E-02 \\
4.2392 E-02 \\
8.2689 E-02 \\
1.8312 E-01 \\
2.2870 E-01 \\
1.9442 E-01 \\
1.3152 E-01 \\
8.0919 E-02 \\
4.8385 E-02 \\
1.9802 E-02 \\
1.2282 E-02\end{array}$ & $\begin{array}{c}f s d \\
\text { total } \\
.08108 \\
.04279 \\
.04141 \\
.07793 \\
.08443 \\
.09007 \\
.04964 \\
.02822 \\
.03521 \\
.03568 \\
.06559 \\
.05819 \\
.06810 \\
.09884\end{array}$ \\
\hline \multicolumn{5}{|c|}{$\begin{array}{l}4 \text { pi } r^{* * 2} \text { group } 28 \text { fluence ( gammas/source) } \\
\text { responses(detector) sambo for } 10 \text { region air }\end{array}$} \\
\hline $\begin{array}{c}\text { detector } \\
\qquad \begin{array}{c}1 \\
2 \\
3 \\
4 \\
5 \\
6 .\end{array}\end{array}$ & $\begin{array}{c}\text { uncoll } \\
\text { response } \\
0.0000 \mathrm{E}+00 \\
0.0000 \mathrm{E}+00 \\
0.0000 \mathrm{E}+00 \\
0.0000 \mathrm{E}+00 \\
0.0000 \mathrm{E}+00 \\
0.0000 \mathrm{E}+00\end{array}$ & $\begin{array}{c}\text { fsd } \\
\text { uncoll } \\
.00000 \\
.00000 \\
.00000 \\
.00000 \\
.00000 \\
.00000\end{array}$ & $\begin{array}{c}\text { total } \\
\text { response } \\
8.0065 \mathrm{E}-02 \\
7.5910 \mathrm{E}-02 \\
5.7970 \mathrm{E}-02 \\
1.9154 \mathrm{E}-02 \\
1.8556 \mathrm{E}-02 \\
6.1707 \mathrm{E}-02\end{array}$ & $\begin{array}{c}\text { fsd } \\
\text { total } \\
.10309 \\
.08078 \\
.09354 \\
.18157 \\
.25745 \\
.18004\end{array}$ \\
\hline $\begin{array}{r}7 \\
8 \\
9 \\
10 \\
11 \\
12 \\
13 \\
14\end{array}$ & $\begin{array}{l}0.0000 E+00 \\
0.0000 E+00 \\
0.0000 E+00 \\
0.0000 E+00 \\
0.0000 E+00 \\
0.0000 E+00 \\
0.0000 E+00 \\
0.0000 E+00\end{array}$ & $\begin{array}{l}.00000 \\
.00000 \\
.00000 \\
.00000 \\
.00000 \\
.00000 \\
.00000 \\
.00000\end{array}$ & $\begin{array}{l}8.5857 E-02 \\
8.5908 E-02 \\
6.6111 E-02 \\
4.2590 E-02 \\
2.3781 E-02 \\
1.5793 E-02 \\
9.2278 E-03 \\
8.9564 E-03\end{array}$ & $\begin{array}{l}.11901 \\
.08017 \\
.11662 \\
.11924 \\
.19755 \\
.17226 \\
.23568 \\
.25858\end{array}$ \\
\hline \multicolumn{5}{|c|}{$\begin{array}{l}4 \text { pi } r^{\star * 2} \text { fast neutron fluence (neutrons/source) } \\
\text { responses(detector) sambo for } 10 \text { region air }\end{array}$} \\
\hline detector & $\begin{array}{c}\text { uncoll } \\
\text { response } \\
2.9455 \mathrm{E}-01 \\
8.6761 \mathrm{E}-02 \\
2.5556 \mathrm{E}-02\end{array}$ & $\begin{array}{c}\text { fsd } \\
\text { uncol } \\
.00013 \\
.00012 \\
.00017\end{array}$ & $\begin{array}{c}\text { total } \\
\text { response } \\
1.6835 \mathrm{E}+00 \\
2.1256 \mathrm{E}+00 \\
1.8546 \mathrm{E}+00\end{array}$ & $\begin{array}{c}\text { fsd } \\
\text { total } \\
.02388 \\
.05465 \\
.02068\end{array}$ \\
\hline
\end{tabular}


Table 8 (continued)

\begin{tabular}{|c|c|c|c|c|}
\hline $\begin{array}{l}4 \\
5 \\
6 \\
7\end{array}$ & $\begin{array}{l}2.2172 E-03 \\
6.5310 E-04 \\
0.0000 E+00 \\
0.0000 E+00\end{array}$ & $\begin{array}{l}.00013 \\
.00004 \\
.00000 \\
.00000\end{array}$ & $\begin{array}{l}1.0854 E+00 \\
7.2959 E-01 \\
1.3744 E+00 \\
1.7668 E+00\end{array}$ & $\begin{array}{l}.03122 \\
.04364 \\
.02288 \\
.01937\end{array}$ \\
\hline \multirow[t]{2}{*}{$\begin{array}{r}8 \\
9 \\
10 \\
11 \\
12 \\
13 \\
14\end{array}$} & $\begin{array}{l}0.0000 E+00 \\
0.0000 E+00 \\
0.0000 E+00 \\
0.0000 E+00 \\
0.0000 E+00 \\
0.0000 E+00 \\
0.0000 E+00\end{array}$ & $\begin{array}{l}.00000 \\
.00000 \\
.00000 \\
.00000 \\
.00000 \\
.00000 \\
.00000\end{array}$ & $\begin{array}{l}2.0580 E+00 \\
1.8887 E+00 \\
1.5445 E+00 \\
1.0944 E+00 \\
6.9138 E-01 \\
3.2199 E-01 \\
2.2335 E-01\end{array}$ & $\begin{array}{l}.01549 \\
.01778 \\
.01641 \\
.02624 \\
.02952 \\
.03716 \\
.06414\end{array}$ \\
\hline & \multicolumn{3}{|c|}{$\begin{array}{l}4 \text { pi } r * * 2 \text { gamma ray fluence (gammas/source) } \\
\text { responses(detector) sambo for } 10 \text { region air }\end{array}$} & \\
\hline detector & $\begin{array}{l}\text { uncoll } \\
\text { response }\end{array}$ & $\begin{array}{l}\text { fsd } \\
\text { uncoll }\end{array}$ & $\begin{array}{l}\text { total } \\
\text { response }\end{array}$ & $\begin{array}{l}\text { fsd } \\
\text { total }\end{array}$ \\
\hline 1 & $0.0000 E+00$ & .00000 & $1.8671 E+00$ & .03590 \\
\hline 2 & $0.0000 E+00$ & .00000 & $2.3374 E+00$ & .03844 \\
\hline 3 & $0.0000 E+00$ & .00000 & $2.0659 E+00$ & .03181 \\
\hline 4 & $0.0000 E+00$ & .00000 & $1.0634 E+00$ & .04872 \\
\hline 5 & $0.0000 E+00$ & .00000 & $7.0830 E-01$ & .06306 \\
\hline $\begin{array}{l}6 \\
7\end{array}$ & $\begin{array}{l}0.0000 E+00 \\
0.0000 E+00\end{array}$ & .00000 & $1.0339 E+00$ & .05670 \\
\hline 8 & $0.0000 E+00$ & .00000 & $2.4037 E+00$ & .02618 \\
\hline 9 & $0.0000 E+00$ & .00000 & $2.1083 E+00$ & .02689 \\
\hline 10 & $0.0000 E+00$ & .00000 & $1.5378 E+00$ & .02931 \\
\hline 11 & $0.0000 E+00$ & .00000 & $1.0625 \mathrm{E}+00$ & .04577 \\
\hline 12 & $0.0000 E+00$ & .00000 & 7.1153E-01 & .04519 \\
\hline 13 & $0.0000 E+00$ & .00000 & $3.7193 E-01$ & .06360 \\
\hline 14 & $0.0000 E+00$ & .00000 & $4.1743 \mathrm{E}-01$ & .08860 \\
\hline
\end{tabular}


Verification

Table 9. Sample Problem 8 for MORSE-SGC

\begin{tabular}{|c|c|c|c|c|}
\hline $\begin{array}{c}\text { detector } \\
1 \\
2\end{array}$ & $\begin{array}{c}\text { uncoll } \\
\text { response } \\
0.0000 \mathrm{E}+00 \\
0.0000 \mathrm{E}+00\end{array}$ & $\begin{array}{c}\text { fsd } \\
\text { uncoll } \\
.00000 \\
.00000\end{array}$ & $\begin{array}{c}\text { total } \\
\text { response } \\
2.6516 \mathrm{E}-02^{a} \\
8.3250 \mathrm{E}-02\end{array}$ & $\begin{array}{c}\text { fsd } \\
\text { total } \\
.04292 \\
.03898\end{array}$ \\
\hline \multicolumn{2}{|c|}{$\begin{array}{l}\text { neutron deaths } \\
\text { killed by russian roulette } \\
\text { escaped } \\
\text { reached energy cutoff } \\
\text { reached time cutoff }\end{array}$} & $\begin{array}{l}\text { number } \\
19458 \\
9698 \\
0 \\
0\end{array}$ & $\begin{array}{c}\text { weight } \\
.14465 E+05 \\
.11894 E+05 \\
.00000 E+00 \\
.00000 E+00\end{array}$ & \\
\hline $\begin{array}{l}\text { number of } \\
\text { medium } \\
1 \\
2 \\
3 \\
4\end{array}$ & $\begin{array}{l}\text { catterings } \\
\text { number } \\
191134 \\
89668 \\
263639 \\
12739\end{array}$ & & & \\
\hline
\end{tabular}




\subsubsection{SAS1 Control Program}

Sample problem results for the SAS1 and SAS1X control programs are presented in Table 10. Table 10 was generated using the FORTRAN utility code READX. The format of the output from READX consists of the results file name followed by a list of the output files scanned. If a string is identified as being from XSDRNPM, the first 20 characters of the title are printed followed by selected output from the module. The value of "lambda" from XSDRNPM is printed, if found, as is the message that the outer iteration limit was exceeded. Following the XSDRNPM results listing, the results from XSDOSE are listed. The format of the READX output gives the detector number followed by the neutron and gamma dose rates for each detector. A lambda of exactly 1.0000 generally means that the XSDRNPM problem was executed in the "fixed source" mode rather than in the "k-eff" mode. The results presented in Table 10 verify that SAS1 and SAS1X are correctly installed.

\subsubsection{SAS4 Control Program}

The SAS4 sample problem results for eight sample problems are given in Tables 11 through 18 . Monte Carlo calculations such as those performed in SAS4 are particularly sensitive to changes in the random number sequence. Minor cross-section differences and differences in the random number generator between two different computers may lead to seemingly large changes in the results. The deviation of the results must be taken into consideration when comparing the code performance between different computer systems. The SAS4 results are consistent with those presented in the SCALE-4.2 bascline. The results presented in Tables 11 through 18 verify that SAS4 is correctly installed.

\subsection{FUNCTIONAL VERIFICATION}

Functional verification consists of running problems that have known results. These problems are not part of the sample problems and are normally only run for code verification. The problems include analytic problems for which the results are known and problems which test specific code capabilities for which there is a known code response.

The functional verification of the shielding software included analysis of problems using BONAMI, NITAWL-II, XSDRNPM, DORT, MORSE, SASI, and SAS4. The BONAMI and NITAWL problems are discussed in Ref. 23 which also contains the tabulated results. The calculations with the other codes are discussed in this report.

Both MORSE-SGC and XSDRNPM solve the Boltzmann transport equation: MORSE-SGC by use of the Monte Carlo method, and XSDRNPM by use of 1-D discrete ordinates. Both codes are used to calculate results for systems for which results are known. In addition, both codes are used to calculate systems for which published results with similar methods and codes are available. These problems provide additional verification that both MORSE-SGC and XSDRNPM yield the same result under appropriate circumstances and are properly solving the underlying equations.

\subsubsection{XSDRNPM/DORT Comparison}

The XSDRNPM and DORT codes use the discrete ordinates method to solve the Boltzmann transport equation in one and two dimensions, respectively. The codes were independently developed and utilize cross sections in entirely different formats. In order to verify that the XSDRNPM code was correctly solving the governing equations, the identical problem was solved using both XSDRNPM and DORT in one dimension. Both codes use the same spatial mesh intervals, but slightly different angular quadrature sets. The neutron and gamma dose rate results at the last three mesh intervals are presented in Table 19. Generally XSDRNPM results are about 3\% higher than those of DORT. 
Table 10. SASI and SASIX sample problem results summary

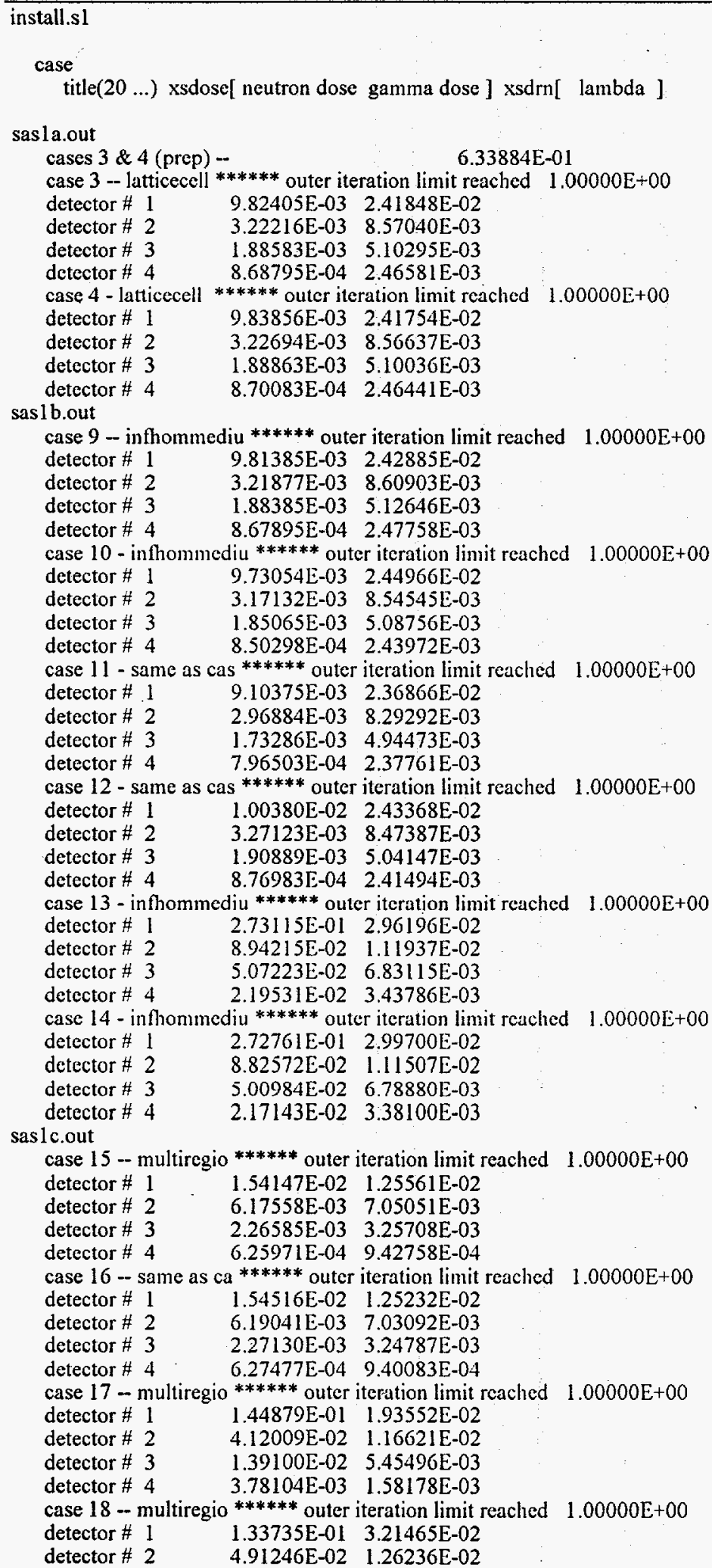


Table 10 (continued)

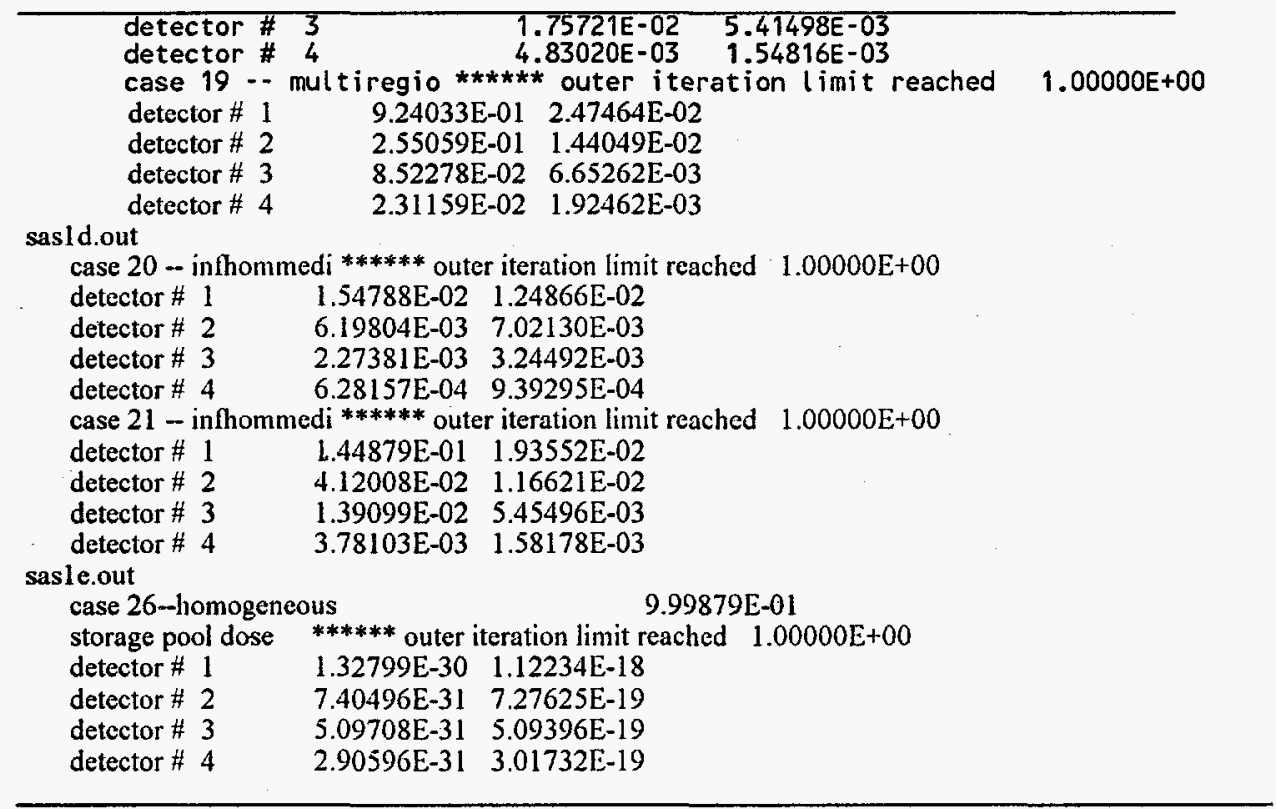

Table 11. Sample Problem 1 for SAS4 Control Program

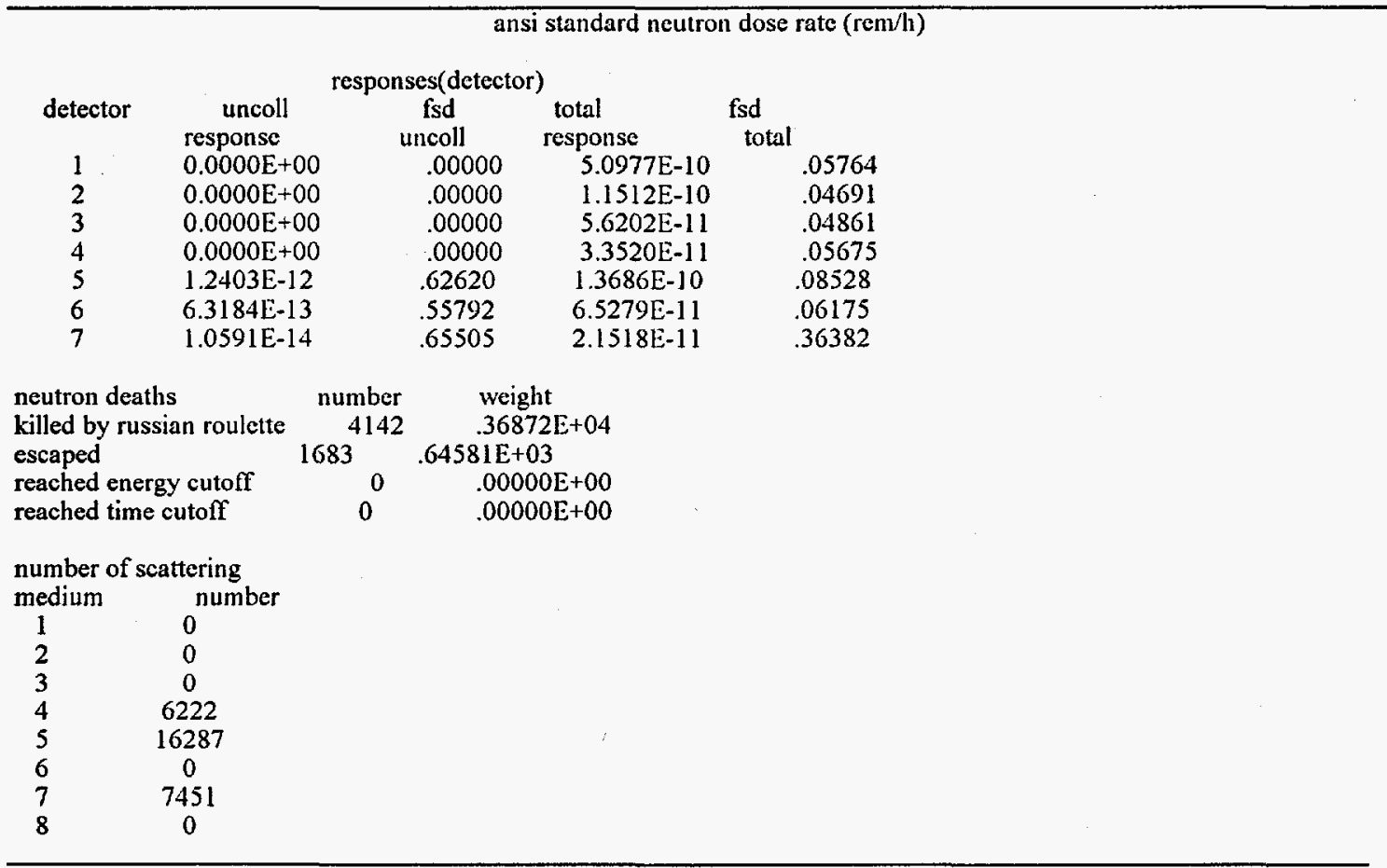


Verification

Table 12. Sample Problem 2 for SAS4 Control Program

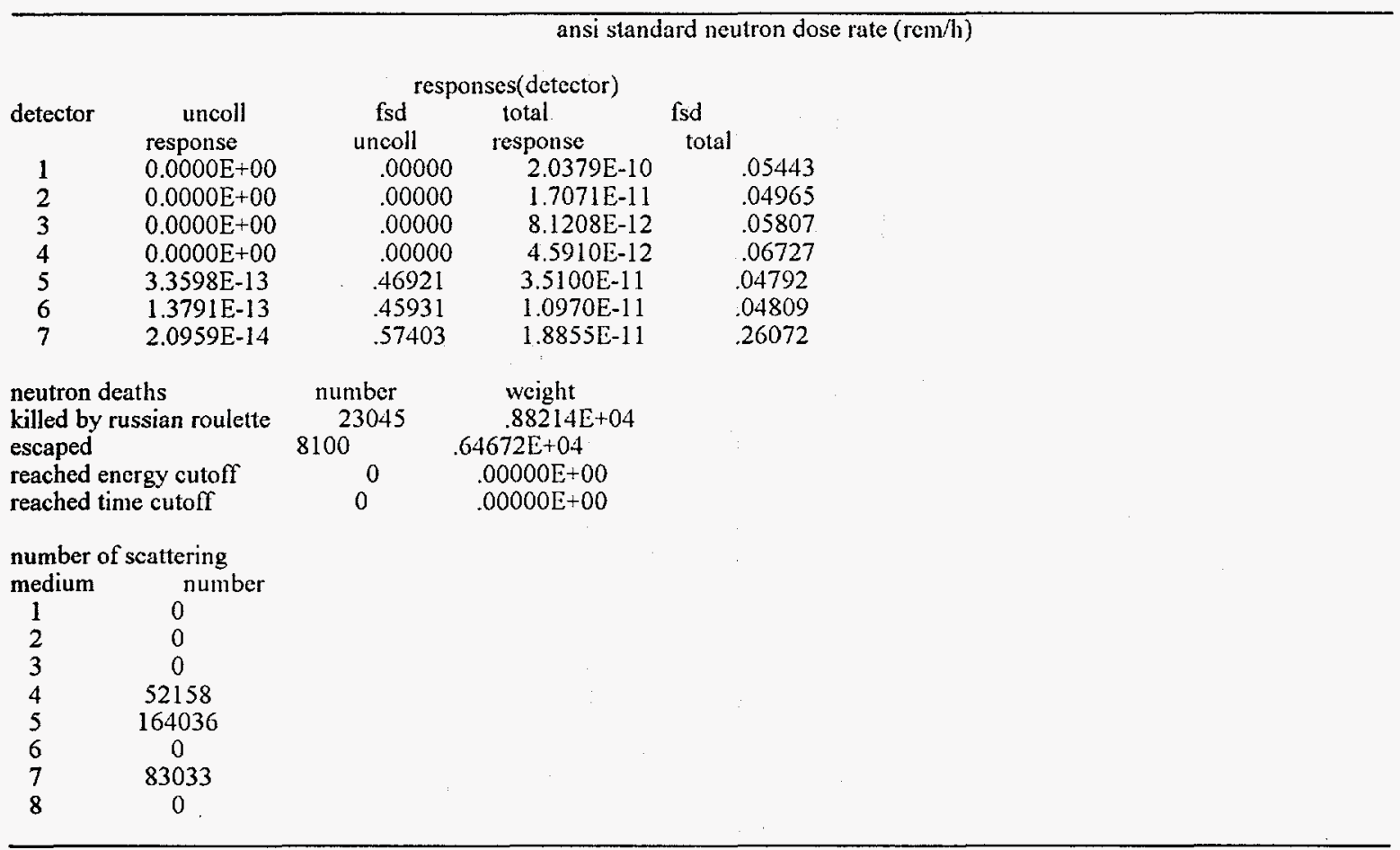

Table 13. Sample Problem 3 for SAS4 Control Program

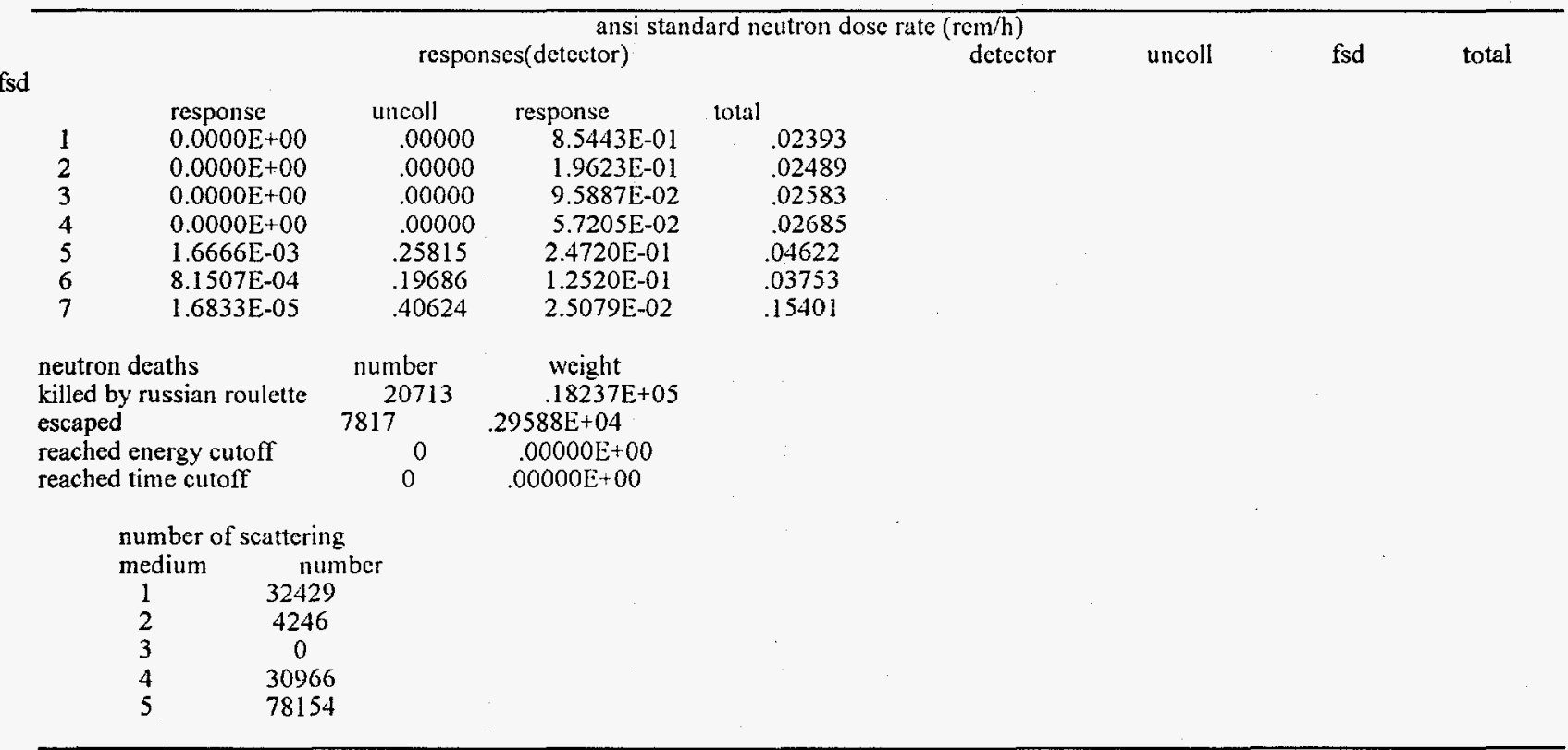


Verification

Table 14. Sample Problem 4 for SAS4 Control Program

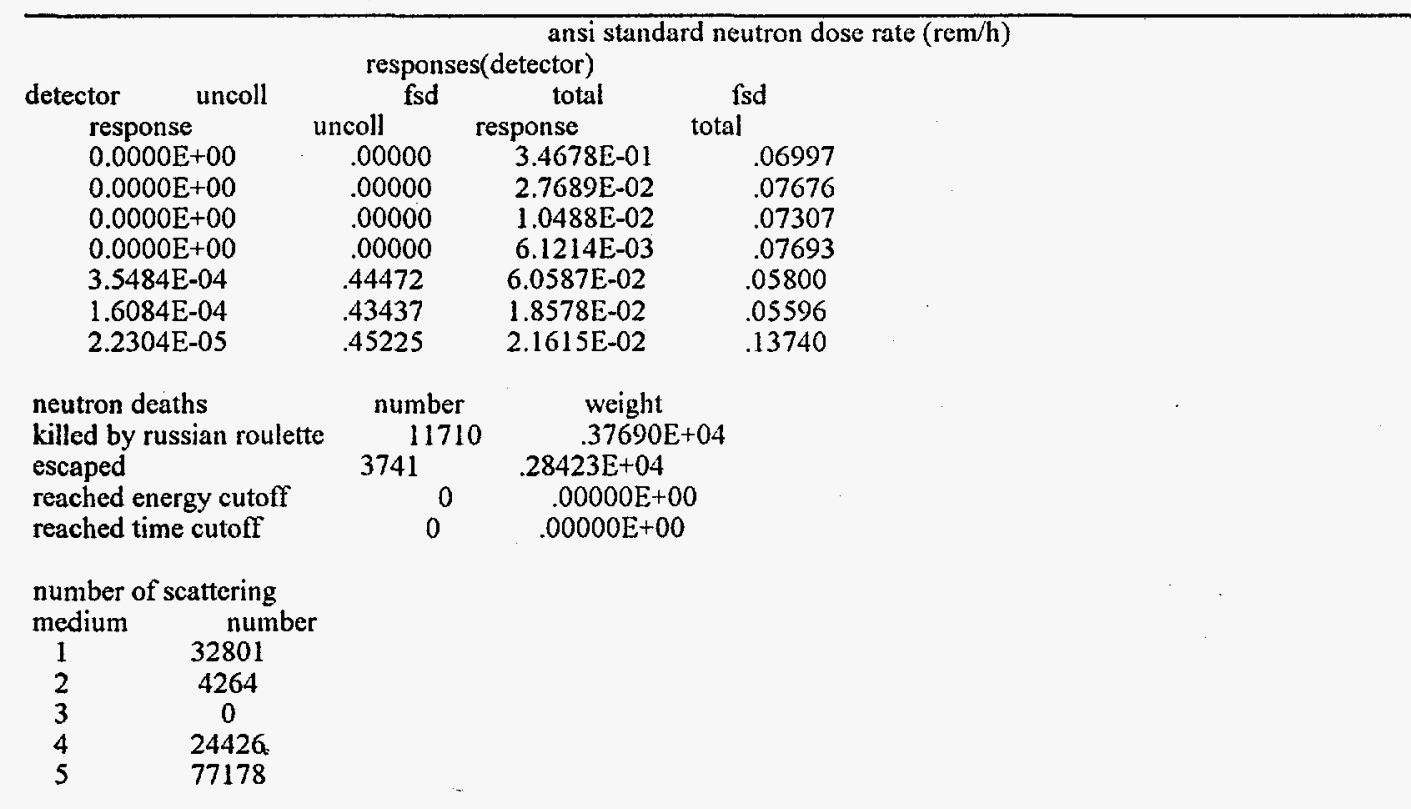

Table 15. Sample Problem 5 for SAS4 Control Program

\begin{tabular}{|c|c|c|c|c|}
\hline & \multicolumn{4}{|c|}{ ansi standard neutron dose rate (rem/h) } \\
\hline & \multicolumn{3}{|c|}{ responses(detector) } & \multirow[b]{2}{*}{$\begin{array}{l}\text { fsd } \\
\text { total }\end{array}$} \\
\hline detector & $\begin{array}{l}\text { uncoll } \\
\text { response }\end{array}$ & $\begin{array}{c}\text { fsd } \\
\text { uncoll }\end{array}$ & $\begin{array}{l}\text { total } \\
\text { response }\end{array}$ & \\
\hline 1 & $0.0000 \mathrm{E}+00$ & .00000 & $9.1253 \mathrm{E}-01$ & .06407 \\
\hline 2 & $0.0000 \mathrm{E}+00$ & .00000 & $2.0025 \mathrm{E}-01$ & .07217 \\
\hline 3 & $0.0000 \mathrm{E}+00$ & .00000 & $9.5534 \mathrm{E}-02$ & .06761 \\
\hline 4 & $0.0000 \mathrm{E}+00$ & .00000 & $5.7084 \mathrm{E}-02$ & .06997 \\
\hline 5 & $1.5079 \mathrm{E}-03$ & .47052 & $2.4518 \mathrm{E}-01$ & .08546 \\
\hline 6 & 8.0343E-04 & .49767 & $1.2011 \mathrm{E}-01$ & .06812 \\
\hline 7 & $1.7637 \mathrm{E}-06$ & .85348 & $2.7856 \mathrm{E}-02$ & .25911 \\
\hline \multirow{5}{*}{\multicolumn{2}{|c|}{$\begin{array}{l}\text { neutron deaths } \\
\text { killed by russian roulette } \\
\text { escaped } \\
\text { reached energy cutoff } \\
\text { reached time cutoff }\end{array}$}} & number & weight & \\
\hline & & 4002 & $.33840 E+04$ & \\
\hline & & 1602 & $.57589 E+03$ & \\
\hline & & 0 & $.00000 \mathrm{E}+00$ & \\
\hline & & 0 & $.00000 \mathrm{E}+00$ & \\
\hline \multicolumn{5}{|c|}{$\begin{array}{l}\text { number of scattering } \\
\text { medium number }\end{array}$} \\
\hline medium & number & & & \\
\hline 1 & 6910 & & & \\
\hline 2 & 5787 & & & \\
\hline 3 & 15457 & & & \\
\hline 4 & 0 & & & \\
\hline 5 & 0 & & & \\
\hline
\end{tabular}


Verification

Table 16. Sample Problem 6 for SAS4 Control Program

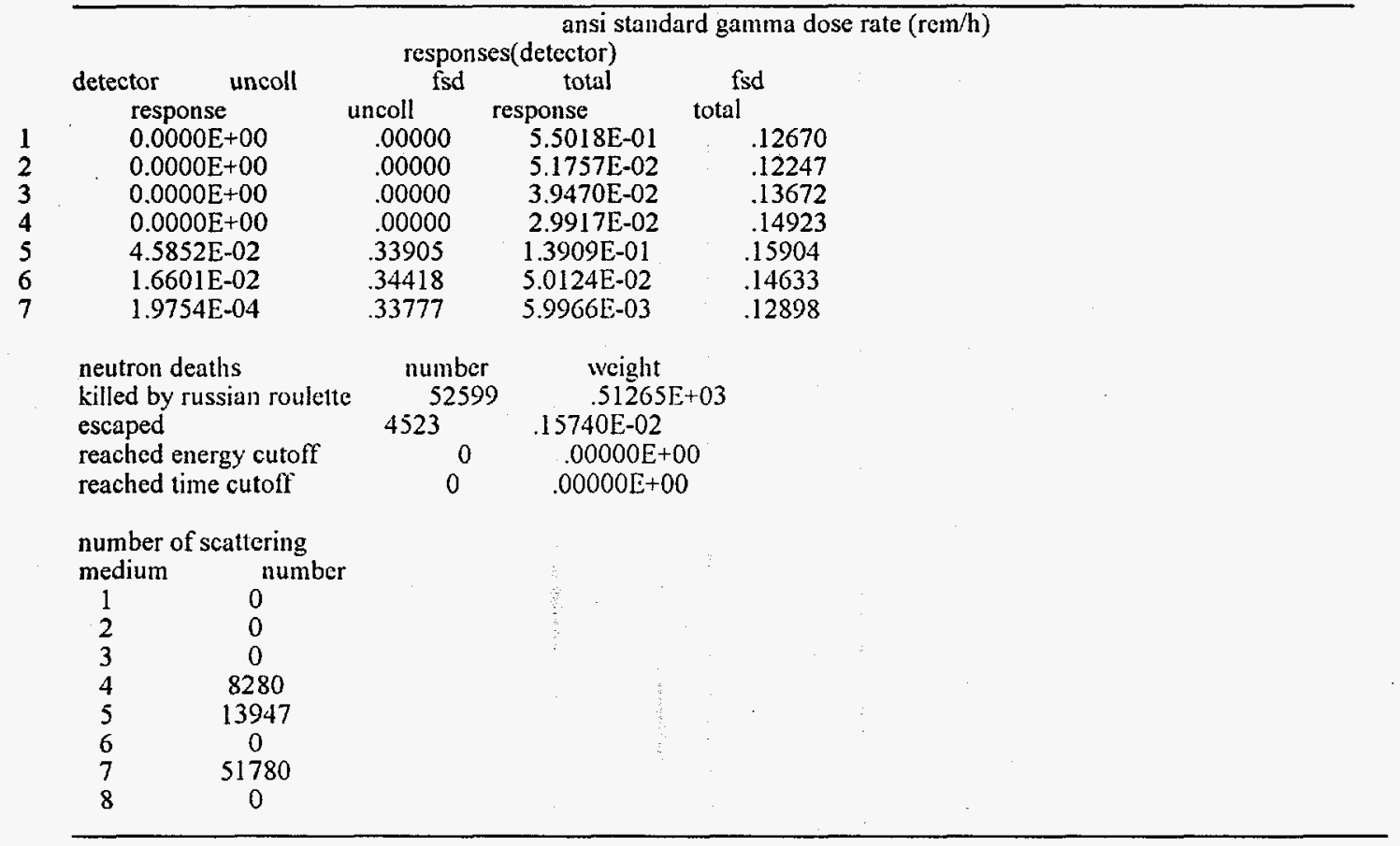

Table 17. Sample Problem 7 for SAS4 Control Program

\begin{tabular}{|c|c|c|c|c|}
\hline detector & \multicolumn{3}{|c|}{$\begin{array}{c}\text { ansi standard gamma dose rate }(\mathrm{rem} / \mathrm{h} \text { ) } \\
\text { responses (detector) }\end{array}$} & \multirow[b]{2}{*}{$\begin{array}{r}\text { fsd } \\
\text { total } \\
.12894 \\
.16911 \\
.17576 \\
.18527 \\
.23292 \\
.13922 \\
.13516 \\
.13755\end{array}$} \\
\hline $\begin{array}{l}\text { detector } \\
1 \\
2 \\
3 \\
4 \\
5 \\
6 \\
7 \\
8\end{array}$ & $\begin{array}{c}\text { uncol } \\
\text { response } \\
0.0000 \mathrm{E}+00 \\
0.0000 \mathrm{E}+00 \\
0.0000 \mathrm{E}+00 \\
0.0000 \mathrm{E}+00 \\
1.6372 \mathrm{E}-04 \\
9.8695 \mathrm{E}-05 \\
5.7168 \mathrm{E}-05 \\
3.6187 \mathrm{E}-05\end{array}$ & $\begin{array}{c}f s d \\
\text { uncol l } \\
.00000 \\
.00000 \\
.00000 \\
.00000 \\
.13276 \\
.11514 \\
.11241 \\
.11175\end{array}$ & $\begin{array}{c}\text { total } \\
\text { response } \\
3.7352 \mathrm{E}-03 \\
1.0607 \mathrm{E}-03 \\
7.2748 \mathrm{E}-04 \\
5.1467 \mathrm{E}-04 \\
5.5669 \mathrm{E}-03 \\
2.1551 \mathrm{E}-03 \\
1.1494 \mathrm{E}-03 \\
6.8521 \mathrm{E}-04\end{array}$ & \\
\hline \multicolumn{2}{|c|}{$\begin{array}{l}\text { neutron deaths } \\
\text { killed by russian roulette } \\
\text { escaped } \\
\text { reached energy cutoff } \\
\text { reached time cutoff }\end{array}$} & $\begin{array}{r}\text { number } \\
111278 \\
62066 \\
0 \\
0\end{array}$ & $\begin{array}{c}\text { weight } \\
.11518 \mathrm{E}+04 \\
.89183 \mathrm{E}-03 \\
.00000 \mathrm{0}+00 \\
.00000 \mathrm{E}+00\end{array}$ & \\
\hline \multicolumn{2}{|c|}{$\begin{array}{cr}\text { number of scattering } & \\
\text { medium } & \text { number } \\
1 & 186830 \\
2 & 0 \\
3 & 352402 \\
4 & 241437 \\
5 & 26594\end{array}$} & & & \\
\hline
\end{tabular}


Verification

Table 18. Sample Problem 8 for SAS4 Control Program

\begin{tabular}{|c|c|c|c|c|c|}
\hline & \multicolumn{4}{|c|}{$\begin{array}{c}\text { ansi standard gansia dose rate (rem/h) } \\
\text { responses (detector) }\end{array}$} & \multirow[b]{2}{*}{$\begin{array}{l}\text { fsd } \\
\text { tota } \\
.0323 \\
.03178 \\
.0336 \\
.03548 \\
.0425 \\
.04710 \\
.0517 \\
.0528\end{array}$} \\
\hline $\begin{array}{c}\text { detector } \\
\qquad \begin{array}{c}1 \\
2 \\
3 \\
4 \\
5 \\
6 \\
7 \\
8\end{array}\end{array}$ & $\begin{array}{c}\text { uncoll } \\
\text { response } \\
0.0000 \mathrm{E}+00 \\
0.0000 \mathrm{E}+00 \\
0.0000 \mathrm{E}+00 \\
0.0000 \mathrm{E}+00 \\
3.1385 \mathrm{E}-17 \\
1.7221 \mathrm{E}-17 \\
9.2813 \mathrm{E}-18 \\
5.6178 \mathrm{E}-18\end{array}$ & & $\begin{array}{l}f s d \\
\text { uncoll } \\
.00000 \\
.00000 \\
.00000 \\
.00000 \\
.12857 \\
.11014 \\
.10810 \\
.10739\end{array}$ & $\begin{array}{c}\text { total } \\
\text { response } \\
3.5464 \mathrm{E}-16 \\
8.0261 \mathrm{E}-17 \\
5.5821 \mathrm{E}-17 \\
3.9181 \mathrm{E}-17 \\
4.4863 \mathrm{E}-16 \\
1.9219 \mathrm{E}-16 \\
9.1164 \mathrm{E}-17 \\
5.2837 \mathrm{E}-17\end{array}$ & \\
\hline \multicolumn{2}{|c|}{$\begin{array}{l}\text { neutron deaths } \\
\text { killed by russian roulette } \\
\text { escaped } \\
\text { reached energy cutoff } \\
\text { reached time cutoff }\end{array}$} & $\begin{array}{r}\text { number } \\
78343 \\
35381 \\
0 \\
0\end{array}$ & & $\begin{array}{c}\text { weight } \\
.11039 \mathrm{E}+06 \\
.10993 \mathrm{E}+02 \\
.00000 \mathrm{E}+00 \\
.00000 \mathrm{E}+00\end{array}$ & \\
\hline \multicolumn{6}{|c|}{ 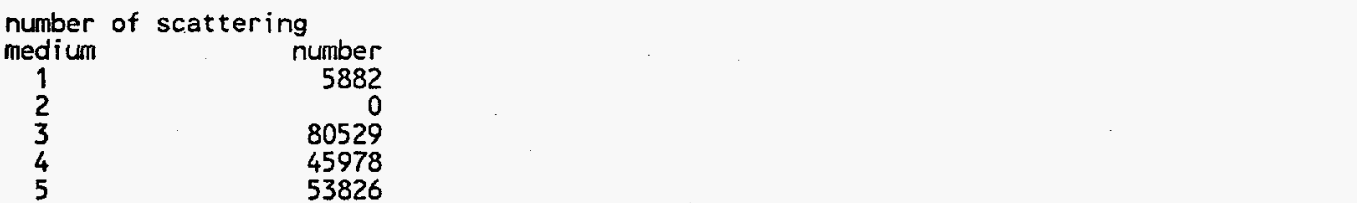 } \\
\hline
\end{tabular}

Table 19. Dose rates (mrem/h) of OECD Problem la calculated by XSDRNPM and DORT

\begin{tabular}{|c|c|c|c|c|c|}
\hline \multirow{2}{*}{$\begin{array}{c}\text { Interval } \\
\text { No. }\end{array}$} & \multirow{2}{*}{$\begin{array}{c}\text { Radial } \\
\text { midpoint } \\
(\mathrm{cm})\end{array}$} & \multicolumn{2}{|c|}{ Neutron } & \multicolumn{2}{|c|}{ Gamma } \\
\hline & & DORT & XSDRNPM & DORT & XSDRNPM \\
\hline 134 & 77.01 & 95.51 & 98.47 & 59.36 & 60.48 \\
\hline 135 & 77.41 & 81.64 & 84.38 & 51.96 & 53.05 \\
\hline 136 & 77.80 & 66.49 & 68.31 & 44.44 & 45.45 \\
\hline
\end{tabular}


Verification

The problem solved in this exercise was OECD problem la which will be further discussed in Sect. 3.2.3. These results verify that the XSDRNPM code is correctly solving the basic discrete ordinates equations.

\subsubsection{MORSE-SGC/MORSE-CGA Comparison}

Eight MORSE-SGC sample problems were summarized in Sect. 3.1.2. Sample problems 4-7 were previously analyzed $^{24}$ with the MORSE-CGA code. Although both MORSE-CGA and MORSE-SGC are based on the same parent code, some 16 years of independent development have given rise to two largely independent codes. Tables 20 through 23 compare the results of MORSE-CGA and MORSE-SGC for sample problems 4 through 7, respectively. Since both codes use Monte Carlo methods with their associated standard deviations, the two sets of results are consistent with each other. Thus the version of MORSE-SGC is verified to be functioning as intended.

\subsubsection{SAS1/SAS4 Comparison}

As an additional means of verifying both the undcrlying computer codes, XSDRNPM and MORSE-SGC, and the shielding analysis sequences, SASI and SAS4, this section presents the application of these code packages to OECD problem 1a. This problem is a simple model of a typical spent fuel cask. The cask consists of a dry cavity of $80 \mathrm{~cm}$ diameter and $450 \mathrm{~cm}$ height, surrounded by a 38-cm-thick cast iron side shield and bottom, and $42 \mathrm{~cm}$ of steel for the cask lid. The source spectrum and magnitude are fixed to determine a computational benchmark problem in which only the cross-section set and computational methodology are allowed to vary.

The SAS 1 and SAS4 solutions to the OECD problem set have been previously published elsewhere. ${ }^{25,26}$ The results from the verification plan are presented in Table 24 as the reference set along with the verification results performed in this study. The reference results are given at the cask side surface and 1,2 , and $10 \mathrm{~m}$ away from the cask side surface. Reference results are given for the SASI and SAS4 codes followed by the results for both the DORT ${ }^{27}$ and MCNP codes. The DORT results (a 2-D discrete-ordinates method) and the MCNP results (a point Monte Carlo method) generally agree to within $10 \%$ of the SASI and SAS4 results. This provides a good indicator of the appropriateness of the individual solution methodologies for this particular problem set.

Table 24 also compares the verification results of the radial dose rates calculated by SAS1 and SAS4 with the reference results. SASI results for the reference and verification cases are in agreement to within $5 \%$ for all cases. Similarly, for the SAS4 results, after accounting for the standard deviations in the Monte Carlo calculations, the reference and verification results are in general agreement. These results verify that the SAS1 and SAS4 control programs are functioning as intended for this series of problems. 
Table 20. Comparison of MORSE-SGC and MORSE-CGA results for sample problem 4

\section{4 pi $r^{* * 2}$ fluence}

IBM RISC 6000 SGC results

$\begin{array}{cc} & \text { detecto } \\ & \text { No. } \\ & \\ & 1 \\ & \\ & \\ & \\ & \\ & \\ & \\ & 4 \\ & 5 \\ & 6 \\ & 6 \\ & 7\end{array}$

neutron deaths

killed by Russian roulette

escaped

reached energy cutoff

reached time cutoff

number of scatterings

medium 1

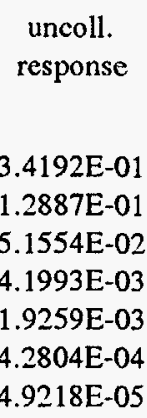

fsd

uncoll.

0.00659

0.01253

0.01822

0.03357

0.03798

0.04595 .

0.05680

No.

weight

238

0
792

1792

0

0

0
No

37727

total

response

$1.8103 \mathrm{E}+0$

$1.8715 \mathrm{E}+0$

$1.6242 \mathrm{E}+0$

5.4490E-01

$3.5945 \mathrm{E}-01$

1.3052E-01

3.8628E-02

$0.16344 E+01$

$0.14556 \mathrm{E}+04$

4. pi $r^{* * 2}$ fluence

IBM RISC 6000 CGA Results

$\begin{array}{lll}\begin{array}{l}\text { fsd } \\ \text { uncoll. }\end{array} & \begin{array}{l}\text { total } \\ \text { response }\end{array} & \begin{array}{l}\text { fsd } \\ \text { total }\end{array} \\ 0.00559 & 2.1246 \mathrm{E}+0 & .08982 \\ 0.01011 & 2.2012 \mathrm{E}+0 & .07505 \\ 0.01437 & 1.8050 \mathrm{E}+0 & .08924 \\ 0.02710 & 6.8964 \mathrm{E}-01 & .08768 \\ 0.03110 & 4.6693 \mathrm{E}-01 & .19685 \\ 0.03842 & 1.8961 \mathrm{E}-01 & .10183 \\ 0.04787 & 3.1405 \mathrm{E}-02 & .08854\end{array}$

neutron deaths

killed by Russian roulette

escaped

reached energy cutoff

reached time cutoff

number of scatterings

medium 1
No. weight

$0.14190 \mathrm{E}+01$

0

$0.15701 \mathrm{E}+04$

0

No

38469 
Table 21. Comparison of MORSE-SGC and MORSE CGA results for sample problem 5

\begin{tabular}{|c|c|c|c|c|c|c|c|c|}
\hline \multicolumn{5}{|c|}{4 pi r ${ }^{* * 2}$ neutron dose rate $\left(\mathrm{cm}^{* * 2} \mathrm{rad} /\right.$ source $)$} & \multicolumn{4}{|c|}{4 pi $\mathrm{r} * 22$ neutron dose rate $\left(\mathrm{cm}^{* * 2} \mathrm{rad} /\right.$ source $)$} \\
\hline \multicolumn{5}{|c|}{ IBM RISC 6000 workstation results } & \multicolumn{4}{|c|}{ IBM RISC 6000 CGA results } \\
\hline detector & $\begin{array}{l}\text { uncoll. } \\
\text { response }\end{array}$ & $\begin{array}{l}\text { fsd } \\
\text { uncoll. }\end{array}$ & $\begin{array}{l}\text { total } \\
\text { response }\end{array}$ & $\begin{array}{l}\text { fsd } \\
\text { total }\end{array}$ & detector & $\begin{array}{l}\text { uncoll. } \\
\text { response }\end{array}$ & $\begin{array}{l}\text { total } \\
\text { response }\end{array}$ & $\begin{array}{l}\text { fsd } \\
\text { total }\end{array}$ \\
\hline 1 & 3.6315E-09 & 0 & $5.9368 \mathrm{E}-09$ & 0.03125 & 1 & 3.6315E-09 & $5.9163 \mathrm{E}-09$ & 0.02028 \\
\hline 2 & $2.9621 \mathrm{E}-09$ & 0.00017 & $5.9944 \mathrm{E}-09$ & 0.02030 & 2 & $2.9621 \mathrm{E}-09$ & $6.0081 \mathrm{E}-09$ & 0.02402 \\
\hline 3 & $2.4162 \mathrm{E}-09$ & 0.00007 & $6.0837 \mathrm{E}-09$ & 0.01161 & 3 & 2.4162E-09 & $6.2945 E-09$ & 0.02065 \\
\hline 4 & $1.6076 \mathrm{E}-09$ & 0.00003 & $5.9268 \mathrm{E}-09$ & 0.03035 & 4 & $1.6076 \mathrm{E}-09$ & $6.2306 \mathrm{E}-09$ & 0.02886 \\
\hline 5 & $4.7353 \mathrm{E}-10$ & 0.00015 & $4.5111 \mathrm{E}-09$ & 0.01677 & 5 & $4.7353 \mathrm{E}-10$ & $4.5683 \mathrm{E}-09$ & 0.03747 \\
\hline 6 & 4.1084E-11 & 0.00015 & $1.9427 \mathrm{E}-09$ & 0.06627 & 6 & 4.1084E-11 & 2.0395E-09 & 0.04118 \\
\hline 7 & $1.8188 \mathrm{E}-11$ & 0.00005 & $1.4891 \mathrm{E}-09$ & 0.04963 & 7 & $1.8188 \mathrm{E}-11$ & $1.4733 \mathrm{E}-09$ & 0.04572 \\
\hline 8 & 3.5645E-12 & 0.00011 & $6.3351 \mathrm{E}-10$ & 0.05068 & 8 & $3.5645 \mathrm{E}-12$ & 7.3367E-10 & 0.06506 \\
\hline 9 & $3.0927 \mathrm{E}-13$ & 0.00005 & $2.2177 \mathrm{E}-10$ & 0.19275 & 9 & $3.0927 \mathrm{E}-13$ & $2.2097 \mathrm{E}-10$ & 0.07137 \\
\hline 10 & $2.6832 \mathrm{E}-14$ & 0.00011 & $4.6922 \mathrm{E}-11$ & 0.06199 & 10 & $2.6832 \mathrm{E}-14$ & $5.3047 \mathrm{E}-11$ & 0.10338 \\
\hline \multicolumn{5}{|c|}{4 pi r**2 gamma dose rate $\left(\mathrm{cm}^{* * 2} \mathrm{rad} /\right.$ source) } & \multicolumn{4}{|c|}{4 pi $\mathrm{r}^{* * 2}$ gamma dose rate $\left(\mathrm{cm}^{* * 2} \mathrm{rad} / \mathrm{source}\right)$} \\
\hline detector & $\begin{array}{l}\text { total } \\
\text { response }\end{array}$ & $\begin{array}{l}\text { fsd } \\
\text { total }\end{array}$ & & & detector & $\begin{array}{l}\text { total } \\
\text { response }\end{array}$ & & $\begin{array}{l}\text { fsd } \\
\text { total }\end{array}$ \\
\hline 1 & $5.8971 \mathrm{E}-10$ & 0.07463 & & & 1 & $6.2053 \mathrm{E}-10$ & & 0.05940 \\
\hline 2 & $8.0956 \mathrm{E}-10$ & 0.05328 & & & 2 & $7.9292 \mathrm{E}-10$ & & 0.04630 \\
\hline 3 & $9.9445 \mathrm{E}-10$ & 0.04316 & & & 3 & $8.9389 \mathrm{E}-09$ & & 0.04430 \\
\hline 4 & $1.1589 \mathrm{E}-09$ & 0.02569 & & & 4 & $1.1208 \mathrm{E}-09$ & & 0.03807 \\
\hline 5 & $1.1439 \mathrm{E}-09$ & 0.02597 & & & 5 & $1.1601 \mathrm{E}-09$ & & 0.01990 \\
\hline 6 & $6.4773 \mathrm{E}-10$ & 0.02692 & & & 6 & $6.2287 \mathrm{E}-10$ & & 0.02411 \\
\hline 7 & $4.9373 \mathrm{E}-10$ & 0.03021 & & & 7 & $5.2094 \mathrm{E}-10$ & & 0.05266 \\
\hline 8 & $2.7453 \mathrm{E}-10$ & 0.03264 & & & 8 & $2.8975 \mathrm{E}-10$ & & 0.04473 \\
\hline 9 & $1.1823 \mathrm{E}-10$ & 0.06700 & & & 9 & $1.1284 \mathrm{E}-10$ & & 0.05760 \\
\hline 10 & $4.9335 \mathrm{E}-11$ & 0.08268 & & & 10 & $4.8233 \mathrm{E}-11$ & & 0.06660 \\
\hline \multicolumn{2}{|c|}{ neutron deaths } & & No. & weight & \multicolumn{2}{|c|}{ neutron deaths } & No. & weight \\
\hline \multirow{2}{*}{\multicolumn{2}{|c|}{$\begin{array}{l}\text { killed by Russian roulette } \\
\text { escaped }\end{array}$}} & & 5472 & $0.49019 E+01$ & \multirow{2}{*}{\multicolumn{2}{|c|}{$\begin{array}{l}\text { killed by Russian roulette } \\
\text { escaped }\end{array}$}} & 5544 & $0.49674 \mathrm{E}+01$ \\
\hline & & & 0 & 0 & & & 0 & 0 \\
\hline \multicolumn{2}{|c|}{ reached energy cutoff } & & 12534 & $0.52371 E+04$ & \multicolumn{2}{|c|}{ reached energy cutoff } & 12385 & $0.51508 E+04$ \\
\hline \multicolumn{2}{|c|}{ reached time cutoff } & & 0 & 0 & \multicolumn{2}{|c|}{ reached time cutoff } & 0 & 0 \\
\hline \multicolumn{2}{|c|}{ number of scatterings } & & \multicolumn{2}{|c|}{ No. } & \multicolumn{2}{|c|}{ number of scatterings } & \multicolumn{2}{|c|}{ No. } \\
\hline \multicolumn{2}{|c|}{ medium 1} & & \multicolumn{2}{|c|}{896906} & medium & & \multicolumn{2}{|c|}{897968} \\
\hline
\end{tabular}


Table 22. Comparison of MORSE-SGC and MORSE-CGA results for sample problem 6

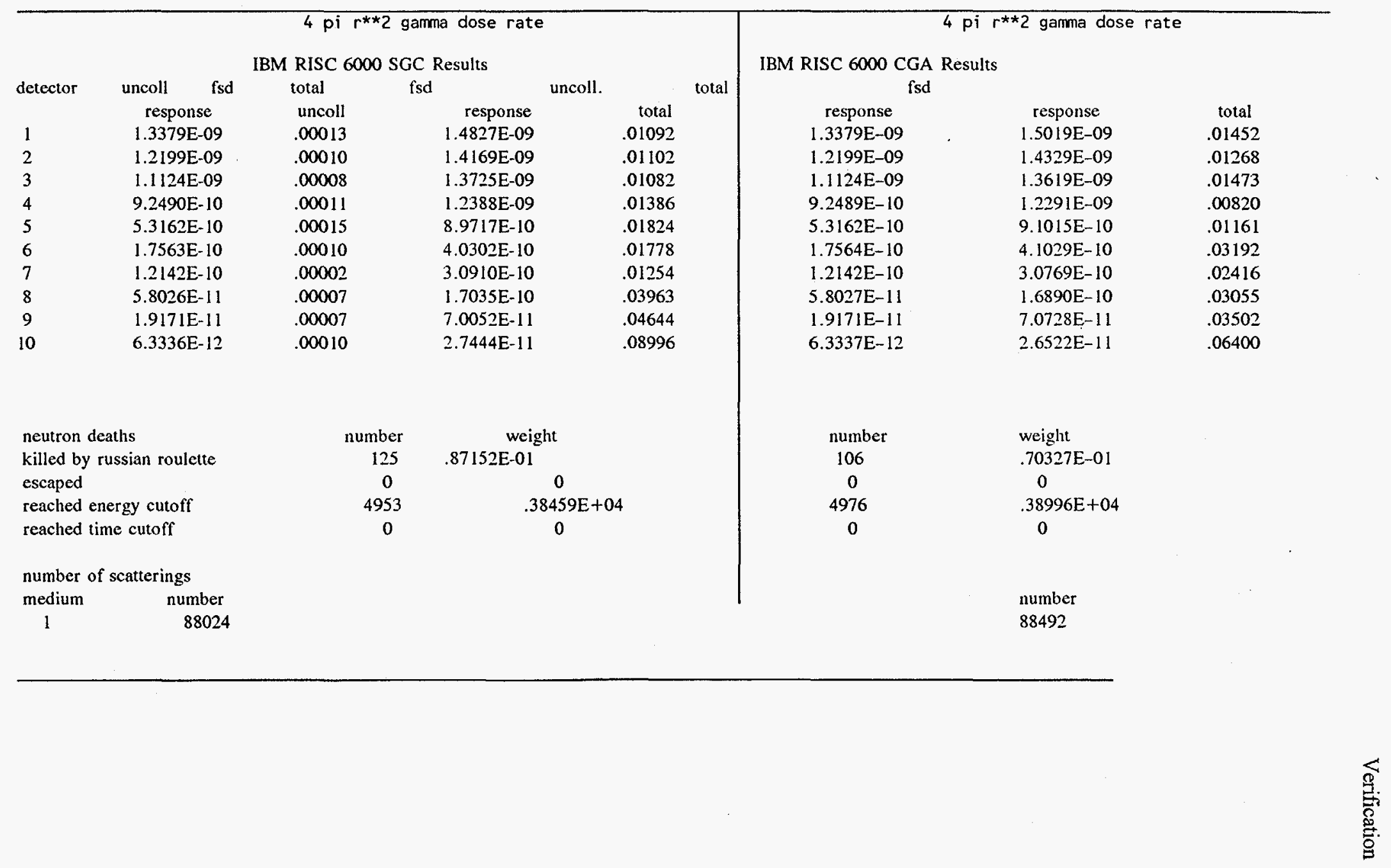


Table 23. Comparison of MORSE-SGC and MORSE-CGA results for sample problem 7

$4 \mathrm{pi} r^{\star \star 2}$ fast neutron fluence (neutrons/source)

IBM RISC 6000 workstation results

$\begin{array}{llll}\begin{array}{l}\text { uncoll. } \\ \text { response }\end{array} & \begin{array}{l}\text { fsd } \\ \text { uncoll. }\end{array} & \begin{array}{l}\text { total } \\ \text { response }\end{array} & \begin{array}{l}\text { fsd } \\ \text { total }\end{array} \\ 2.9455 E-01 & 0.00013 & 1.6835 E+0 & 0.02388 \\ 8.6761 E-02 & 0.00012 & 2.1256 E+0 & 0.05465 \\ 2.5556 E-02 & 0.00017 & 1.8546 E+0 & 0.02068 \\ 2.2172 E-03 & 0.00013 & 1.0854 E+0 & 0.03122 \\ 6.5310 E-04 & 0.00004 & 7.2959 E-01 & 0.04364 \\ 0 & 0 & 1.3744 E+0 & 0.02288 \\ 0 & 0 & 1.7668 E+0 & 0.01937 \\ 0 & 0 & 2.0580 E+0 & 0.01549 \\ 0 & 0 & 1.8887 E+0 & 0.01778 \\ 0 & 0 & 1.5445 E+0 & 0.01641 \\ 0 & 0 & 1.0944 E+0 & 0.02624 \\ 0 & 0 & 6.9138 E-01 & 0.02952 \\ 0 & 0 & 3.2199 E-01 & 0.03716 \\ 0 & 0 & 2.2335 E-01 & 0.06414\end{array}$

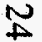

4 pi $r^{* * 2}$ garma fluence (gammas/source)

$$
\begin{array}{lc}
\text { detector } & \begin{array}{c}
\text { total } \\
\text { response }
\end{array} \\
1 & 1.8671 \mathrm{E}+0 \\
2 & 2.3374 \mathrm{E}+0 \\
3 & 2.0659 \mathrm{E}+0 \\
4 & 1.0634 \mathrm{E}+0 \\
5 & 7.0830 \mathrm{E}-01 \\
6 & 1.0339 \mathrm{E}+0 \\
7 & 1.9054 \mathrm{E}+0 \\
8 & 2.4037 \mathrm{E}+0 \\
9 & 2.1083 \mathrm{E}+0 \\
10 & 1.5378 \mathrm{E}+0 \\
11 & 1.0625 \mathrm{E}+0 \\
12 & 7.1153 \mathrm{E}-01 \\
13 & 3.7193 \mathrm{E}-01 \\
14 & 4.1743 \mathrm{E}-01
\end{array}
$$

neutron deaths

killed by Russian roulette escaped

reached energy cutoff

reached time cutoff
No.

$\begin{array}{rl}4107 & 0.38345 E+01 \\ 0 & 0 \\ 7940 & 0.42919 E+04 \\ 0 & 0\end{array}$

4 pi $r^{\star * 2}$ fast neutron fluence (neutrons/source)

IBM RISC 6000 CGA results

$\begin{array}{llll}\text { detector } & \begin{array}{l}\text { uncoll. } \\ \text { response }\end{array} & \begin{array}{l}\text { total } \\ \text { response }\end{array} & \begin{array}{l}\text { fsd } \\ \text { total }\end{array} \\ 1 & 2.9455 \mathrm{E}-01 & 1.6928 \mathrm{E}+0 & 0.03639 \\ 2 & 8.6761 \mathrm{E}-02 & 2.0253 \mathrm{E}+0 & 0.02228 \\ 3 & 2.5556 \mathrm{E}-02 & 1.8840 \mathrm{E}+0 & 0.02222 \\ 4 & 2.2172 \mathrm{E}-03 & 1.1060 \mathrm{E}+0 & 0.03684 \\ 5 & 6.5310 \mathrm{E}-04 & 6.9022 \mathrm{E}-01 & 0.03722 \\ 6 & 0 & 1.3909 \mathrm{E}+0 & 0.02295 \\ 7 & 0 & 1.8074 \mathrm{E}+0 & 0.02169 \\ 8 & 0 & 2.0747 \mathrm{E}+0 & 0.01526 \\ 9 & 0 & 1.9017 \mathrm{E}+0 & 0.01680 \\ 10 & 0 & 1.4803 \mathrm{E}+0 & 0.01718 \\ 11 & 0 & 1.0764 \mathrm{E}+0 & 0.02773 \\ 12 & 0 & 6.9534 \mathrm{E}-01 & 0.02799 \\ 13 & 0 & 3.4195 \mathrm{E}-01 & 0.04300 \\ 14 & 0 & 2.0063 \mathrm{E}-01 & 0.05856\end{array}$

4 pi $r^{* * 2}$ garma fluence (gammas/source)

fsd
total

0.03590
0.03844
0.03181
0.04872
0.06306
0.05670
0.03597
0.02618
0.02689
0.02931
0.04577
0.04519
0.06360
0.08860

total

fsd

detector

response

total

1
2
3
4
5
6
7
8
9
10
11
12
13
14

$\begin{array}{ll}1.7018 E+0 & 0.03956 \\ 2.2348 E+0 & 0.03149 \\ 2.0450 E+0 & 0.03551 \\ 1.1018 E+0 & 0.04874 \\ 6.7627 E-01 & 0.04220 \\ 9.3182 E-01 & 0.05875 \\ 1.8204 E+0 & 0.03318 \\ 2.2993 E+0 & 0.02376 \\ 2.1673 E+0 & 0.02942 \\ 1.5650 E+0 & 0.02954 \\ 1.0783 E+0 & 0.04665 \\ 6.9116 E-01 & 0.03681 \\ 3.7549 E-01 & 0.05538 \\ 4.0906 E-01 & 0.08352\end{array}$

neutron deaths

No. weight

killed by Russian roulette

escaped

reached energy cutoff

reached time cutoff
$4112 \quad 0.38410 E+01$

00

$\begin{array}{rl}8018 & 0.42438 E+04\end{array}$ 
Table 24. Radial dose rate (mrem/h) comparison for OECD Problem la

\begin{tabular}{|c|c|c|c|c|c|c|}
\hline & \multicolumn{3}{|c|}{ Reference results } & \multicolumn{3}{|c|}{ Veritication results } \\
\hline & Neutron & $\begin{array}{l}\text { Primary } \\
\text { gamma }\end{array}$ & $\begin{array}{l}\text { Secondary } \\
\text { gamma }\end{array}$ & Neutron & $\begin{array}{l}\text { Primary } \\
\text { gamma }\end{array}$ & $\begin{array}{l}\text { Secondary } \\
\text { gamma }\end{array}$ \\
\hline \multicolumn{7}{|l|}{ Surface } \\
\hline$\overline{\text { SAS1 }}$ & 62.0 & 41.7 & 0.41 & $\begin{array}{l}59.5 \\
(-4 \%)^{b}\end{array}$ & $\begin{array}{l}41.4 \\
(-1 \%)\end{array}$ & $\begin{array}{l}0.42 \\
(2 \%)\end{array}$ \\
\hline SAS4-avg. & $58.0(0.02)^{\mathrm{a}}$ & $37.0(0.04)$ & $0.35(0.07)$ & $\begin{array}{l}55.7(0.02) \\
(-4 \%)\end{array}$ & $\begin{array}{l}39.3(0.05) \\
(6 \%)\end{array}$ & $\begin{array}{l}0.36(0.04) \\
(3 \%)\end{array}$ \\
\hline DORT-avg. & 57.4 & 36.3 & 0.38 & - & - & - \\
\hline MCNP-avg. & $64.1(0.02)$ & $34.1(0.07)$ & $0.46(0.08)$ & - & - & - \\
\hline \multicolumn{7}{|l|}{1 meter } \\
\hline SAS1 & 19.2 & 16.0 & 0.13 & $\begin{array}{l}18.4 \\
(-4 \%)\end{array}$ & $\begin{array}{l}15.9 \\
(1 \%)\end{array}$ & $\begin{array}{l}0.14 \\
(<8 \%)\end{array}$ \\
\hline SAS4 & $18.8(0.02)$ & $20.0(0.20)$ & $0.11(0.25)$ & $\begin{array}{l}17.7(0.02) \\
(-6 \%)\end{array}$ & $\begin{array}{l}14.4(0.14) \\
(-28 \%)\end{array}$ & $\begin{array}{l}0.12(0.05) \\
(9 \%)\end{array}$ \\
\hline DORT & 18.3 & 15.5 & 0.13 & - & - & - \\
\hline MCNP & $20.8(0.02)$ & $13.5(0.10)$ & $0.14(0.06)$ & - & - & - \\
\hline \multicolumn{7}{|l|}{2 meters } \\
\hline$\overline{\text { SAS1 }}$ & 10.7 & 9.7 & 0.08 & $\begin{array}{l}10.2 \\
(-5 \%)\end{array}$ & $\begin{array}{l}9.6 \\
(-1 \%)\end{array}$ & $\begin{array}{l}0.08 \\
(0 \%)\end{array}$ \\
\hline SAS4 & $10.0(0.02)$ & $11.9(0.30)$ & $0.04(0.08)$ & $\begin{array}{l}9.40(0.02) \\
(-6 \%)\end{array}$ & $\begin{array}{l}7.41(0.09) \\
(-38 \%)\end{array}$ & $\begin{array}{l}0.06(0.04) \\
(<50 \%)\end{array}$ \\
\hline DORT & 9.5 & 8.7 & 0.07 & - & - & - \\
\hline MCNP & $11.1(0.02)$ & $7.7(0.07)$ & $0.08(0.05)$ & - & - & - \\
\hline \multicolumn{7}{|l|}{10 meters } \\
\hline SAS1 & 0.95 & 1.17 & 0.007 & $\begin{array}{l}0.91 \\
(-4 \%)\end{array}$ & $\begin{array}{l}1.16 \\
(-1 \%)\end{array}$ & $\begin{array}{l}0.007 \\
(0 \%)\end{array}$ \\
\hline SAS4 & $0.80(0.18)$ & $1.03(0.13)$ & $0.005(0.19)$ & $\begin{array}{l}0.78(0.02) \\
(-3 \%)\end{array}$ & $\begin{array}{l}1.21(0.12) \\
(17 \%)\end{array}$ & $\begin{array}{l}0.005(0.04) \\
(0 \%)\end{array}$ \\
\hline DOR'T & 0.78 & 0.95 & 0.006 & - & - & - \\
\hline MCNP & $0.91(0.02)$ & $0.85(0.06)$ & $0.006(0.04)$ & - & - & - \\
\hline
\end{tabular}

Fractional standard deviation in Monte Carlo calculations.

${ }^{b}$ Percent difference between the verification and reference results. 


\section{VALIDATION}

\subsection{INTRODUCTION}

The purpose of this section is to present the results of a radiation shielding validation of SASI/XSDRNPM and MORSE-SGC using the 27N-18COUPLE SCALE cross-section library. Results using XSDRNPM via the SAS1 sequence are presented for only a few of the cases since most of the experimental configurations are multidimensional in nature.

The experimental models used for the validation were taken from previously documented studies. ${ }^{28}$ The experiments modeled cover a fairly broad range of cask-type systems and spent fuel enrichments and cooling times. No descriptions or discussions of the experiments will be given in this report; however, the availability of the calculational models is discussed in Appendix A.

Unlike the criticality safety validation study, where a large number of benchmark quality experiments are available to provide good coverage for most practical applications, radiation shielding applications largely depend on a few tailored experiments very specific to each particular area. For radiation shielding analyses of spent fuel transportation/storage cask applications, the required number of experiments to completely envelop all situations would indeed be large. For cxample, currently there are several gamma shield materials; iron, lead, depleted uranium, and concrete; several neutron shielding materials; epoxy resins, water, ethylene glycol, polyethylene; a wide range of fuel enrichments from about 2.0 to $5.0 \mathrm{wt} \%{ }^{235} \mathrm{U}$; spent fucl burnups ranging from 20 to $60 \mathrm{GWd} / \mathrm{MTU}$; and spent fuel cooling times ranging from 6 months to 15 years. Each of these parameter ranges would need experimental coverage for the validation results to be completely general. Therefore, a general validation for spent fuel cask applications is impractical, since the required number of benchmark measurements is not available. The regulatory approach to this problem has been to require a measurement to be performed prior to each shipment of spent fuel. This approach tends to decrease the regulatory requircments for radiation shielding computational validation. However, this does not completely solve the problem from a practical standpoint when optimal, cost-effective radioactive material packaging is desired. The use of simple but conservative approximations can lead to overly conservative and hence, non-cost-effective designs.

Recent trends in package development have concentrated on cost-effective, optimal designs where multidimensional analysis techniques become necessary. The use of better computational methods and the corresponding decrease in conservatism has the effect of increasing the level of validation required. This validation has taken a dual approach to assuring the quality of the radiation shielding applications to spent fuel cask analysis and design. The first step involves the analysis of simple shielding benchmarks consisting of the attenuation of both neutron and gamma-ray point sources through standard cask materials of varying thicknesses. These benchmark problems primarily allow the performance of the cross sections through varying thicknesses of shielding materials to be validated. This is particularly useful since the solution methodology and geometry modeling aspects of the code have already largely been validated through the code verification procedures (see Sect. 3).

In order for these simple benchmarks to be truly realistic, the point sources used must be typical of those seen for spent fuel. The neutron source spectrum from spent fucl is largely a fission spectrum and thus changes little with burnup or cooling time. The ${ }^{252} \mathrm{Cf}$ spontaneous fission point source is thercfore representative of nearly all neutron sources from spent fuel. The neutron experiments have becn performed with iron, polyethylene, graphite, and a number of other shielding materials. For completeness, further experiments are needed on lead and depleted uranium shield materials. The gamma-ray source spectrum for spent fucl results from the decay gamma rays for a number of individual fission products. Over the first 100-year period of decay after the end of irradiation, some 8 to 10 fissionproduct and activation isotopes dominate the contribution to the gamma-ray dose rates from spent fuel. These isotopes have very different decay times and characteristic gamma-ray spectra. Thus, gamma-ray benchmark 
experiments need to be performed for most or all of these isotopes. At present, only a ${ }^{60} \mathrm{Co}$ source has been applied in these benchmark experiments.

In the absence of complete benchmark information for attenuation characteristics of various neutron and gamma-ray spectra, the second step for validation includes the analysis of actual spent fuel cask measurements. Due to the complexity and expense of these measurements the number of available experiments is rather small. However, these experiments allow a good overall representation of the expected accuracies of actual spent fuel cask dose-rate analyses to be evaluated.

In Sect. 4.2 the sources of the simple benchmark and cask experiment models are given. The calculational results and analysis of the data are presented in Sect. 4.3.

\subsection{PROBLEM DESCRIPTION}

The simple benchmark and cask experiment.validation models were taken from a previous study ${ }^{28}$ which included application of SAS1 and SAS4 sequences. The models were obtained from the authors of the report and were used unaltered.

The simple benchmark problems executed for this validation study included 18 neutron dose-rate calculations and 6 gamma-ray dose-rate calculations. The neutron dose measurements were performed using $\mathrm{a}^{252} \mathrm{Cf}$ source while the photon measurements utilized a ${ }^{60} \mathrm{Co}$ source. The measurement configuration consisted of a point source followed by 0 to $35 \mathrm{~cm}$ of steel, graphite, or polyethylene for the neutron measurements and 0 to $25 \mathrm{~cm}$ of steel for the gammaray measurements. The shielding material consisted of $80-\times 80-\mathrm{cm}$ slabs located approximately $1 \mathrm{~m}$ from the source. These problems can be approximately modeled in one dimension; however, a paraffin source collimator cannot be modeled effectively in one dimension and represents a source of approximation.

The storage casks included in this analysis were the Ventilated Storage Cask (VSC), a reinforced concrete cask loaded with 17 consolidated fuel canisters, the TN-24P forged steel storage cask loaded with 24 unconsolidated pressurizedwater-reactor (PWR) spent fuel assemblies and with 24 consolidated fucl canisters, the Westinghouse MC-10 forged steel storage cask with 24 PWR spent fuel assemblies, and the CASTOR-V/21 nodular cast-iron storage cask loaded with 21 PWR spent fuel assemblies. The spent fuel burnup ranged from 24 to $36 \mathrm{GWd} / \mathrm{MTU}$, with enrichments from 1.9 to $3.2 \mathrm{wt} \%{ }^{235} \mathrm{U}$, and cooling times from 2 to 14 years. The fuel assemblies were Westinghouse $15 \times 15$ PWR assemblies irradiated from 1973 to 1983 in the Surry-2 reactor, or from 1974 to 1977 in the Turkey Point reactor.

\subsection{RESULTS AND DISCUSSION}

The simple benchmarks described in the previous section were analyzed with both SAS1 and SAS4. The neutron results are given in Tables 25 through 27 for graphite, iron, and polyethylene shields, respectively. The maximum deviations for the SAS4 3-D results from the measured results are $15 \%, 17 \%$, and $27 \%$ for the three shields. Most of the 3-D results for these benchmark problems are overestimates. The SAS1 1-D neutron results show similar trends to the 3-D results with the exception of the zero-thickness cases. Here the backscatter from the paraffin collimator is not accounted for, resulting in an underprediction for these cases. Once any appreciable attenuation occurs, the neutron backscatter becomes relatively unimportant. The maximum deviations for the $1-\mathrm{D}$ results are $39 \%, 45 \%$, and $24 \%$, which are generally larger than those of the 3-D results due to the geometry approximations. 
Validation

Table 25. Comparison of measured and calculated neutron dose rates for graphite slabs

\begin{tabular}{lccccc}
\hline & \multicolumn{5}{c}{ Dose equivalent rate $(\mu \mathrm{Sv} / \mathrm{h})$} \\
\cline { 2 - 6 } $\begin{array}{l}\text { Thickness } \\
(\mathrm{cm})\end{array}$ & Experiment & $\begin{array}{c}\text { SAS1 } \\
\text { calculation }\end{array}$ & C/E & $\begin{array}{c}\text { SAS4 } \\
\text { calculation }\end{array}$ & C/E \\
\hline 0 & 176.2 & 133.4 & 0.76 & $203.3(1 \%)$ & 1.15 \\
5 & 131.3 & 131.4 & 1.00 & $146.8(2 \%)$ & 1.12 \\
15 & 66.4 & 74.8 & 1.13 & $75.4(3 \%)$ & 1.14 \\
20 & 45.5 & 52.7 & 1.16 & - & \\
25 & 30.8 & 36.9 & 1.20 & $34.8(4 \%)$ & 1.13 \\
35 & 13.5 & 18.8 & 1.39 & $15.3(6 \%)$ & 1.13 \\
\hline
\end{tabular}

Table 26. Comparison of measured and calculated neutron dose rates for iron slabs

\begin{tabular}{|c|c|c|c|c|c|}
\hline \multirow[b]{2}{*}{$\begin{array}{l}\text { Thickness } \\
(\mathrm{cm})\end{array}$} & \multicolumn{5}{|c|}{ Dose equivalent rate $(\mu \mathrm{Sv} / \mathrm{h})$} \\
\hline & Experiment & $\begin{array}{c}\text { SAS1 } \\
\text { calculation }\end{array}$ & $\mathrm{C} / \mathrm{E}$ & $\begin{array}{c}\text { SAS4 } \\
\text { calculation }\end{array}$ & $\mathrm{C} / \mathrm{E}$ \\
\hline 0 & 165.3 & 123.5 & 0.75 & $184.5(1 \%)$ & 1.12 \\
\hline 5 & 118.2 & 123.4 & 1.04 & $136.9(2 \%)$ & 1.16 \\
\hline 15 & 62.5 & 79.2 & 1.27 & $69.2(5 \%)$ & 1.11 \\
\hline 20 & 46.3 & 60.9 & 1.32 & - & \\
\hline 25 & 34.6 & 46.6 & 1.35 & $33.2(5 \%)$ & 0.96 \\
\hline 35 & 19.0 & 27.5 & 1.45 & $15.8(7 \%)$ & 0.83 \\
\hline
\end{tabular}


Table 27. Comparison of measured and calculated neutron dose rates for polyethylene slabs

\begin{tabular}{|c|c|c|c|c|c|}
\hline \multirow[b]{2}{*}{$\begin{array}{l}\text { Thickness } \\
\text { (cm) }\end{array}$} & \multicolumn{5}{|c|}{ Dose equivalent rate $(\mu \mathrm{Sv} / \mathrm{h})$} \\
\hline & Experiment & $\begin{array}{c}\text { SAS1 } \\
\text { calculation }\end{array}$ & $\mathrm{C} / \mathrm{E}$ & $\begin{array}{c}\text { SAS4 } \\
\text { calculation }\end{array}$ & $\mathrm{C} / \mathrm{E}$ \\
\hline 0 & 683.0 & 517.1 & 0.76 & $779.0(1 \%)$ & 1.14 \\
\hline 5 & 288.0 & 258.8 & 0.90 & $354.0(3 \%)$ & 1.23 \\
\hline 15 & 42.6 & 42.1 & 0.99 & $54.2(6 \%)$ & 1.27 \\
\hline 20 & 18.3 & 17.7 & 0.97 & - & \\
\hline 25 & 8.3 & 7.7 & 0.93 & $10.2(6 \%)$ & 1.23 \\
\hline 35 & 2.25 & 1.7 & 0.76 & $2.15(9 \%)$ & 0.96 \\
\hline
\end{tabular}

Table 28. Comparison of measured and calculated photon dose rates for iron slabs

\begin{tabular}{|c|c|c|c|c|c|}
\hline \multirow[b]{2}{*}{$\begin{array}{l}\text { Thickness } \\
\text { (cm) }\end{array}$} & \multicolumn{5}{|c|}{ Dose equivalent rate $(\mu \mathrm{Sv} / \mathrm{h})$} \\
\hline & Experiment & $\begin{array}{c}\text { SAS1 } \\
\text { calculation }\end{array}$ & $\mathrm{C} / \mathrm{E}$ & $\begin{array}{c}\text { SAS4 } \\
\text { calculation }\end{array}$ & $\mathrm{C} / \mathrm{E}$ \\
\hline 0 & 1020.0 & 769.1 & 0.75 & $980.0(1 \%)$ & 0.96 \\
\hline 5 & 255.0 & 220.6 & 0.87 & - & \\
\hline 10 & 60.0 & 45.2 & 0.75 & - & \\
\hline 15 & 9.62 & 8.24 & 0.87 & $10.4(7 \%)$ & 1.08 \\
\hline 20 & 1.67 & 1.41 & 0.84 & $1.54(5 \%)$ & 0.92 \\
\hline 25 & 0.34 & 0.24 & 0.71 & $0.29(6 \%)$ & 0.85 \\
\hline
\end{tabular}


The gamma-ray results for the simple geometry benchmarks are given in Table 28 for shield thicknesses from 0 to $25 \mathrm{~cm}$ of iron. The results generally agree reasonably well with the measurements for both the 1- and 3-D cases, with maximum deviations of $29 \%$ and $15 \%$, respectively.

These benchmark results are useful since they give the expected cross-section performance as a function of the shield thickness. Other uncertainties must of course be considered for actual cask calculations, such as the source and material concentration uncertainties. Typically the material concentrations are chosen to give conservative results. Additional benchmark experiments of this type are needed to provide complete coverage for the various cask materials (i.e., lead, depleted uranium, as well as additional gamma sources ${ }^{137} \mathrm{Cs},{ }^{154} \mathrm{Eu},{ }^{134} \mathrm{Cs}$, ${ }^{144} \mathrm{Pr}$, etc.). In the absence of additional benchmark quality simple experiments, individual cask measurements for a variety of cask types are useful to study common trends in the calculated versus measured results. These results can also be used to demonstrate the overall validity of the calculational procedures.

The cask results included in this validation work are largely due to the work included in the verification plan. To ensure consistency with the published results, selected cask problems were transferred to the validation computer and reanalyzed to ensure consistency. In all cases the results were consistent within the Monte Carlo statistical uncertainties of the two sets of results.

The complete cask results using the standard SCALE 27N-18COUPLE library are given in Table 29. For the neutron and photon results in Table 29 , a number of trends are noted. With the exception of the three cask side measurements below $4 \mathrm{mrem} / \mathrm{h}$, the neutron doses agree with measurements to within $30 \%$. It appears that the three measurements below $4 \mathrm{mrem} / \mathrm{h}$ have significant uncertainties. For gamma-ray doses on the cask side, an overprediction of the measured results by over a factor of 2 is seen. Some of the causes of this overprediction will be discussed later. The gamma dose trends for the cask lid and bottom are reasonably consistent (agreement to within 30\%), with several exceptions. The low predicted gamma dose rate for the VSC lid appears to be due to the presence of thermocouple penetrations in the lid that were not modeled. The overprediction of the TN-24P bottom measurements for consolidated fuel are reasonably consistent with the trend seen for gamma doses on the cask side. This was somewhat expected since the bottom endfittings were removed in the consolidation process, and hence only the active fuel contributes to the bottom doses.

In an effort to determine the causes of the overprediction of gamma doses on the cask side, revised calculations were performed at selected detector locations for all cask configurations. Revisions included the use of a 44-gamma-group library for the gamma-ray transport, a newly generated 44-neutron-group library ${ }^{29}$ for the source-term predictions, and an approximate representation of the cooling fins for the TN-24P cask. The 44-neutron-group library was used in the source-generation calculation to predict the spectra at various stages of burnup. This library is primarily based on ENDF/B-V but contains ENDF/B-VI cross section for ${ }^{154} \mathrm{Eu}$ and ${ }^{155} \mathrm{Eu}$. These Eu isotopes are important for both spent fuel source terms and burnup credit application, and major updates were made in the ENDF/B-VI evaluation. The effect of these cross-section changes was enhanced ${ }^{154} \mathrm{Eu}$ capture and, hence, decreases of some 30 to $40 \%$ in the ${ }^{154} \mathrm{Eu}$ inventories in the spent fuel. Gamma rays from ${ }^{154} \mathrm{Eu}$ are a major contributor to the total doses along the cask side surfaces.

The updated gamma dose-rate results indicate little effect along the cask lid and bottom as expected since the dominant contributor in these areas, ${ }^{60} \mathrm{Co}$, was unchanged from the previous calculations. The gamma side doses show significant reductions for all cask configurations. These doses continue to exhibit similar trends for both iron and concrete gamma shields. The gamma side dose-rate predictions are still higher than the experimental values by an average factor of about 1.6. The fact that all of these casks have similar calculated to experimental ratios indicates a common or similar source of the overpredictions. Due to the large amount of attenuation (about 5 orders of magnitude) as little as a $4 \%$ increase in the iron or concrete cross sections or densities could account for this overprediction. 
Table 29. Summary of SAS4 3-D dose-rate results

\begin{tabular}{|c|c|c|c|c|c|c|c|}
\hline & & \multicolumn{3}{|c|}{ Neutron $(\mathrm{mrem} / \mathrm{h})$} & \multicolumn{3}{|c|}{ Gamma (mrem/h) } \\
\hline & & Calc. & Meas. & $\begin{array}{l}\text { Ratio } \\
(\mathrm{c} / \mathrm{m})^{\mathrm{c}}\end{array}$ & Calc. & Meas. & $\begin{array}{l}\text { Ratio } \\
(\mathrm{c} / \mathrm{m})^{\mathrm{c}}\end{array}$ \\
\hline \multirow[t]{5}{*}{ Side } & $M C-10(91.5)^{\mathrm{a}}$ & $21.6(2)$ & 19.6 & 1.10 & $45.9(2)^{d}$ & 21.4 & 2.15 \\
\hline & Castor (91.5) & & 11.4 & 0.75 & $76.4(4)$ & 30.2 & 2.53 \\
\hline & TN-24 (91.5) & $8.5(2)$ & 2.8 & 0.47 & $33.4(1)$ & 12.3 & 2.71 \\
\hline & TN-24 con. (91.5) & $1.3(2)$ & 4.0 & 0.43 & $13.9(2)$ & 5.8 & 2.40 \\
\hline & VSC $(91.5)$ & $\begin{array}{l}1.7(1) \\
1.9(1)\end{array}$ & 1 & 1.90 & $44.5(2)$ & 20 & 2.22 \\
\hline \multirow[t]{5}{*}{ Lid } & $M C-10(80 \times 80)^{b}$ & & 56.7 & 1.02 & $21.8(1)$ & 14.6 & 1.49 \\
\hline & Castor $(40.0)$ & $58.0(2)$ & 51.5 & 0.98 & $25.8(3)$ & 38.4 & 0.67 \\
\hline & $\mathrm{TN}-24(58.2)$ & $50.6(4)$ & 28.5 & 1.09 & $39.9(1)$ & 37.9 & 1.05 \\
\hline & $\mathrm{TN}-24$ con. (58.2) & $31.0(4)$ & 31.7 & 1.02 & $9.2(1)$ & 12.7 & 0.72 \\
\hline & VSC (58.2) & $\begin{array}{l}32.2(3) \\
7.7(2)\end{array}$ & 10 & 0.77 & $3.4(3)$ & 10 & 0.34 \\
\hline \multirow[t]{4}{*}{ Bottom } & MC-10 $(80 \times 80)$ & & 4.6 & 1.30 & $52.5(1)$ & 62.0 & 0.85 \\
\hline & Castor (40.0) & $6.0(3)$ & 51.3 & 1.07 & $29.3(3)$ & 24.5 & 1.20 \\
\hline & TN-24 (58.2) & $54.9(3)$ & 57.9 & 1.30 & $129.1(1)$ & 117.0 & 1.10 \\
\hline & $\mathrm{TN}-24$ con.(58.2) & $\begin{array}{l}75.6(3) \\
79.2(2)\end{array}$ & 75.8 & 1.05 & $10.1(2)$ & 3 & 3.36 \\
\hline
\end{tabular}

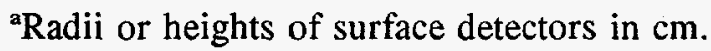

${ }^{b} \mathrm{MC}-10$ axial surface detectors are $80 \mathrm{~cm}$ by $80 \mathrm{~cm}$.

${ }^{c}$ Calculated/measured.

${ }^{\mathrm{d}}$ Percent standard deviations.

\subsection{CONCLUSIONS}

The general trends seen in this work are agreement with $30 \%$ or better with the measurements for neutron dose rates along the cask side, lid, and bottom. The gamma-ray dose rates with substantial contributions from the top endfitting, plenum, and bottom endfitting regions are also in good agreement. Based on the SCALE 27N-18COUPLE library, gamma-ray dose-rate calculations with major contributions due to the active fuel show over a factor of 2 overprediction of the measured quantities for casks with iron and concrete shields. Significant uncertainties exist in the quantification of ${ }^{59} \mathrm{Co}$ concentrations in the endfitting hardware materials. The results shown here support the accuracy of source generation and dose estimation methods in these regions given accurate impurity characterizations. Thus it is felt that the practice of using upper bounds for ${ }^{59} \mathrm{Co}$ initial concentrations should assure conservative cask calculations.

Fortunately the gamma-ray dose discrepancies seen along the cask sides for both the iron and concrete shield surfaces are overpredictions. While these overpredictions are not totally understood, the trends observed, combined with the other verification and validation results, should allow confidence to be placed in the shielding results for a shipping/storage package. 


\section{REFERENCES}

1. SCALE, AModular Code System for Performing Standardized Computer Analyses for Licensing Evaluation, NUREG/CR-200, Rev. 4 (ORNL/NUREG/CSD-2/R4), Vol. I- III (April 1995). Available from Radiation Shielding Information Center, Oak Ridge Natl. Lab., as CCC-545.

2. J. F. Briesmeister, Ed., MCNP - A General Monte Carlo Neutron Particle Transport Code, Version 4A, LA-12625-M, Los Alamos Natl. Lab., 1993.

3. K. D. Lathrop and F. W. Brinkley, TWOTRAN-II, An Interfaced, Exportable Version of the TWOTRAN Code for Two-Dimensional Transport, LA-4848-MS, Los Alamos Natl. Lab., July 1973.

4. M. B. Emmett, The MORSE Monte Carlo Radiation Transport Code System, ORNL-4972 (1975), ORNL-4972/R1 (1983), ORNL-4972/R2 (1984), Union Carbide Corp., Nucl. Div., Oak Ridge Nat1. Lab.

5. M.B. Emmett, MORSE-CGA, A Monte Carlo Radiation Transport Code With Array Geometry Capability, ORNL-6174, Martin Marietta Energy Systems, Inc., Oak Ridge Natl. Lab., April 1985.

6. J. T. West, T. J. Hoffman, and M. B. Emmett, "MORSE-SGC for the SCALE System," Sect. F9 of SCALE: A Modular Code System for Performing Standardized Computer Analyses for Licensing Evaluation, NUREG/CR-200, Rev. 4 (ORNL/NUREG/CSD-2/R4), Vols I, II, and III, April 1995.

7. N. M. Greene and L. M. Petrie, "XSDRNPM: A One-Dimensional Discrete-Ordinates Code for Transport Analysis," Sect. F3 of SCALE: A Modular Code System for Performing Standardized Computer Analyses for Licensing Evaluation, NUREG/CR-200, Rev. 4 (ORNL/NUREG/CSD-2/R4), Vols I, II, and III, April 1995.

8. J. R. Knight et al., "SAS1: A One-Dimensional Shiclding Analysis Module," Sect. S1 of SCALE: A Modular Code System for Performing Standardized Computer Analyses for Licensing Evaluation, NUREG/CR-200, Rev. 4 (ORNL/NUREG/CSD-2/R4), Vols I, II, and III, April 1995.

9. J. S. Tang, "SAS4: A Monte Carlo Cask Shielding Analysis Module Using an Automated Biasing Procedure," Sect. S4 of SCALE: A Modular Code System for Performing Standardized Computer Analyses for Licensing Evaluation, NUREG/CR-200, Rev. 4 (ORNL/NUREG/CSD-2/R4), Vols I, II, and III, April 1995.

10. SCALE Baseline Revision Report, BRR 94-003, May 2, 1994.

11. B. L. Broadhead, Verification and Validation Plan for the SCALE Code System, SCALE CCV-001, Rev. 1, April 1996.

12. M. B. Emmett, "Configuration Management Plan for the SCALE Code System," SCALE-CMP-001, Rev. 5, April 1996.

13. N. M. Greene, "BONAMI: Resonance Self-Shielding by the Bondarenko Method," Sect. F1 of SCALE: $A$ Modular Code System for Performing Standardized Computer Analyses for Licensing Evaluation, NUREG/CR-200, Rev. 4 (ORNL/NUREG/CSD-2/R4), Vols I, II, and III, April 1995.

14. N. M. Greene et al., AMPX-77: A Modular Code System for Generating Coupled Multigroup Neutron-Gamma Cross-Section Libraries from ENDF/B-IV and/or ENDF/B-V, ORNL/CSD/TM-283, Martin Marietta Energy Systems, Inc., Oak Ridge Natl. Lab., October 1992. 
15. N. M. Greene, L. M. Petrie and R. M. Westfall, "NITAWL-II: SCALE System Module for Performing Resonance Shielding and Working Library Production," Sect. F2 of SCALE: A Modular Code System for Performing Standardized Computer Analyses for Licensing Evaluation, NUREG/CR-200, Rev. 4 (ORNL/NUREG/CSD-2/R4), Vols I, II, and III, April 1995.

16. N. M. Greene et al., XLACS: A Program to Produce Weighted Multigroup Neutron Cross Sections from ENDF/B, ORNL/TM-3646, Union Carbide Corp., Nucl. Div., Oak Ridge Natl. Lab., April 1972.

17. R. E. MacFarlane and D. W. Muir, The NJOY Nuclear Data Processing System, Version 91, LA-12740-M, (UC-413), Los Alamos Natl. Lab., October 1994.

18. J. A Bucholz et al., "Standard Composition Library," Sect. M8 SCALE: A Modular Code System for Performing Standardized Computer Analyses for Licensing Evaluation, NUREG/CR-200, Rev. 4 (ORNL/NUREG/CSD-2/R4), Vols I, II, and III, April 1995.

19. N. F. Landers, L. M. Petrie, and J. A. Bucholz, "The Material Information Processor for SCALE", Sect. M7 of SCALE: A Modular Code System for Performing Standardized Computer Analyses for Licensing Evaluation, NUREG/CR-200, Rev. 4 (ORNL/NUREG/CSD-2/R4), Vols I, II, and III, April 1995.

20. J. A. Bucholz, "XSDOSE: A Module for Calculating Fluxes and Dose Rates at Points Outside a Shield," Sect. F4 of SCALE: A Modular Code System for Performing Standardized Computer Analyses for Licensing Evaluation, NUREG/CR-200, Rev. 4 (ORNL/NUREG/CSD-2/R4), Vols I, II, and III, April 1995.

21. N. F. Landers and L. M. Petrie, "CSAS: Control Module for Enhanced Criticality Safety Analysis Sequences," Sect. C4 of SCALE: A Modular Code System for Performing Standardized Computer Analyses for Licensing Evaluation, NUREG/CR-200, Rev. 4 (ORNL/NUREG/CSD-2/R4), Vols I, II, and III, April 1995.

22. N. M. Greene, "User's Guide for Utility Modules," Sect. M15 of SCALE: A Modular Code System for Performing Standardized Computer Analyses for Licensing Evaluation, NUREG/CR-200, Rev. 4 (ORNL/NUREG/CSD-2/R4), Vols I, II, and III, April 1995.

23. W. C. Jordan and M. B. Emmett, Guide to Verification and Validation of the SCALE-4 Criticality Safety Software, NUREG/CR-6483 (ORNL/TM-12834), Lockheed Martin Energy Research Corp., Oak Ridge Natl. Lab. (1996).

24. M. B. Emmett, Verification of the MORSE-SGC on the CRAY UNICOS System, ORNL/NPR-92/5, Martin Marietta Energy Systems, Inc., Oak Ridge Natl. Lab., March 1992.

25. B. L. Broadhead, M. C. Brady, and C. V. Parks, Benchmark Shielding Calculations for the NEACRP Working Group on Transportation Packages, ORNL/CSD/TM-272, Martin Marietta Energy Systems, Inc., Oak Ridge Natl. Lab., November 1990.

26. C. V. Parks et al, Assessment of Shielding Analysis Methods, Codes, and Data for Spent Fuel Transport/Storage Applications, ORNL/CSD/TM-246, Martin Marietta Energy Systems, Inc., Oak Ridge Natl. Lab., July 1988.

27. W. A. Rhoades and R. L. Childs, "The DORT Two-Dimensional Discrete Ordinates Transport Code," Nucl. Sci. Eng. 99, 88-89 (May 1988). 
References

28. B. L. Broadhead et al., Evaluation of Shielding Analysis Methods in Spent Fuel Shipping Cask Environments, EPRI-TR 104329, May 1995.

29. M. D. DeHart and S. M. Bowman, Validation of the SCALE Broad Structure 44-Group ENDF-B/V Cross Section Library for Use in Criticality Safety Analyses, ORNL/TM-12460 (NUREG/CR-6102), Martin Marietta Energy Systems, Inc., Oak Ridge Natl. Lab., September, 1994. 


\section{APPENDIX A}

\section{VERIFICATION/VALIDATION INPUT}

In order for users to perform the verification and/or validation described in this report, the input files for the problems must be available. This appendix contains two tables that correlate input files with the results presented in this document. Table A.l provides information on the verification problems; Table A. 2 does likewise for the validation problems. Users should refer to the SCALE homepage on the World Wide Web which can be accessed from http://www.cad.ornl.gov for additional information on accessing these input files. 
Appendix A

Table A.1 Input files for SCALE shielding code verification

File Names

BONAMIINP

NITAWL.INP

XSDRN.INP

XSDOSE.INP

MORSEI.INP-MORSE8.INP

SASIA.INP-SASIFX.INP

SAS4A.INP-SAS4H.INP

XSDRN.S1

DORTN.IN, DORTG.IN

INA.S I

INA*.S4

DORTINEA, DORTIGEA
Description

BONAMI Sample Problems

NITAWL Sample Problems

XSDRNPM Sample Problems

XSDOSE Sample Problems

MORSE Sample Problems

SASI Sample Problems

SAS4 Sample Problems

XSDRN Cases for Table 19

DORT Cases for Table 19

SAS1 Cases for Table 24

SAS4 Cases for Table 24

DORT Cases for Table 24 
Table A.2 Input files for SCALE shiclding code validation

File Names

UEKII.S4 - UEKI5.S4

UEKII1.S4 - UEKII5.S4

UEKI31.S4 - UEKI35.S4

UEKI21.S4, UEKI24.S4-UEKI26.S4

UEKIGPH.S 1

UEKICST.S 1

UEKIPLY.S 1

UEKIGAM.SI

MCTOPxx.INP

MCBTMxx.INP

MCRADXx.INP

C21Txx.INP

C21Bxx.INP

C21Rxx.INP

INPUTxx.T24

INPUTxx.C24

INPUTxx.VSC

\section{Description}

SAS4 Cases for Table 25

SAS4 Cases for Table 26

SAS4 Cases for Table 27

SAS4 Cases for Table 28

SAS1 Cases for Table 25

SASI Cases for Table 26

SAS1 Cases for Table 27

SAS1 Cases for Table 28

MC-10 Cask Top Cases - Table 29

MC-10 Cask Bottom Cases

MC-10 Cask Radial Cases

CASTOR Cask Top Cases - Table 29

CASTOR Cask Bottom Cases

CASTOR Cask Radial Cases

TN-24P Cask Cases - Table 29

TN-24P Consolidated Fuel Cases

VSC Cask Cases 



\section{APPENDIX B}

\section{UTILITY CODE LISTINGS}

Attached is a list of the computer program READX used to process outputs for XSDOSE and SAS1 programs.

program readx

character iline*132,iline $0 * 132$, icase*12, aeg*11, keff*6, sigma*6

character index $* 12$, results $* 40$, plots $* 40$, title*21, lambda*11

character stats*12,error*36,lib*3,grps*3,neutron*19,gamma*19

logical iflag

cwcj

integer ipt*1

c This program scans the file list in the INDEX file for certain

c xsdose and xsdrn output. The findings are edited into several

c output files.

cwcj

c

c 'INDEX' has a list of output files that are to be scanned

c $(\max$ length filename $=12$ ).

write(*,'(1x,al)') 'enter the index file name $\ldots>$ '

$\operatorname{read}(*, '(a) ')$ index

C

c 'RESULTS' contains an edit of the casename, title, and xsdose or xsdrn

c results only if a string is found to contain a search string.

c

write(*,'(lx,al)') 'enter the results file name --->

$\operatorname{read}\left(*,{ }^{\prime}(a) '\right)$ results

is $=1$

open $(7$, file $=$ index $)$

open $(8$, file $=$ results $)$

write $\left(8, '(1 x, a, /)^{\prime}\right)$ results

write $(8,2000)$

2000 format $(5 x$, 'case',/,t11, 'title(20 ...)',2x, 'xsdose[',1x, 'neutron',

*' dose',2x,'gamma dose',1x,']',2x, 'xsdrn[',3x, 'lambda',2x,']',/)

c ik and ix are counters to help in editing files with multiple outputs.

c

$$
\begin{array}{ll}
\mathrm{ik} & =0 \\
\mathrm{ix} & =0
\end{array}
$$

c outer control loop

10 continue

$\operatorname{read}\left(7,{ }^{\prime}(\mathrm{a} 12)^{\prime}\right.$, end $\left.=40\right)$ icase

ilib $=0$

neut $=0$

title $=$, ,

error $=$, ,

aeg $=$,

keff $=$ ',

sigma $=$, ,

lambda $=$, , 
Appendix B

iline $=$,

iline $0=$ ',

neutron $=$, ,

gamma $=$, ,

write $(*, '(1 \mathrm{x}, \mathrm{a}))$ icase

inquire $($ file $=$ icase, exist $=$ iflag $)$

if(iflag) then

write $(8, '(1 \mathrm{x}, \mathrm{a})$ ') icase

open $(10$, file $=$ icase,err $=41)$

20 iline $0=$ iline

$\operatorname{read}\left(10,{ }^{\prime}(a)^{\prime}\right.$, end $\left.=42\right)$ iline

c check for xsdrn stuff

if(iline(21:26).eq. 'lambda') then

c we found some xsdrn stuff

lambda $=$ iline(29:39)

c now get the title

$\operatorname{read}(10$, '(a)') iline

c . check iteration limit

if(iline(10:14).eq.'outer') then

error $=$ iline $(3: 39)$

write (*,' $(1 \mathrm{x}, \mathrm{a})$ ') error

$\operatorname{read}\left(10,{ }^{\prime}(a) '\right)$ iline

end if

read(10,'(a)') iline

title $=$ iline $(24: 44)$

c go ahead and print it and skip the counter check

write( $\left.8,(t 8, a, t 30, a, t 69, a)^{\prime}\right)$ title,error, lambda

title $=$,

error $=$, ,

lambda $=$, ,

neut $=0$

goto 20

end if

c look for xsdose information

c

if(iline(54:60).eq.' (total)') then

neut $=$ neut +1

if(mod(neut,2).eq.0) then

gamma $=$ iline $(40: 50)$

ndet $=$ int (neut $/ 2)$

write( 8 ,'(t8,10hdetector \#,i3,t34,a,t48,a)') ndet, neutron, gamma

neutron $=$, ,

gamma $=$, ,

goto 20

endif

neutron $=$ iline $(40: 50)$

goto 20

endif

goto 20

endif

goto 10

41 write ${ }^{*}$, , $(1 \mathrm{x}, \mathrm{a})$ ') 'file not found'

goto 10 
42 write(*,' $(1 \mathrm{x}, \mathrm{a})$ ') 'EOF in output' close(10)

goto 10

40 write(*,' $(1 \mathrm{x}, \mathrm{a})$ ') 'EOF in index'

close(8)

close(9)

close (10)

if(is.eq. 1) then

write $(11,1002)$ ik

1002 format $(/, t 2$,'\#of obs $=,, 13)$ close(11)

end if

stop 40

end 
Appendix B 


\section{INTERNAL DISTRIBUTION}

\begin{tabular}{|c|c|}
\hline 5 & S. M. Bowman \\
\hline 6. & B. L. Broadhead \\
\hline 7 & J. A. Bucholz \\
\hline 8 & R. L. Childs \\
\hline 9 & S. N. Cramer \\
\hline 10 & R. D. Dabbs \\
\hline 11 & M. D. DeHart \\
\hline 12 & H. R. Dyer \\
\hline 13 & M. B. Emmett \\
\hline 14 & O. W. Hermann \\
\hline 15 & D. F. Hollenbach \\
\hline 16 & C. M. Hopper \\
\hline 17 & D. T. Ingersoll \\
\hline 18 & W. C. Jordan \\
\hline 19 & B. L. Kirk/R. W. Roussin \\
\hline 20 & M. A. Kuliasha \\
\hline 2. & K. Lewis \\
\hline 2 & J. J. Lichtenwalter \\
\hline 23 & S. B. Ludwig \\
\hline & G. E. Michaels \\
\hline & B. D. Murphy \\
\hline
\end{tabular}
26-30. L. F. Norris
31. J. V. Pace
32. C. V. Parks
33. L. M. Petric
34. R. T. Primm
35. C. E. Pugh
36. R. C. Robinson
37. J. C. Ryman
38. D. B. Simpson
39. C. O. Slater
40. J. S. Tang
41. R. M. Westfall
42. J. E. White
43. B. A. Worley
44. R. Q. Wright
45. Central Research Library
46. ORNL Y-12 Research Library
Document Reference Section
47-48. Laboratory Records Department
49. Laboratory Records, ORNL (RC)
50. ORNL Patent Office

\section{EXTERNAL DISTRIBUTION}

51. F. Alcorn, Babcock \& Wilcox - NNFD, P.O. Box 785, M/C 46, Lynchburg, VA 24505

52. R. Anderson, General Nuclear Systems, Inc., 220 Stoneridge Dr., Columbia, SC 29210

53. C. E. Apperson, Westinghouse Savannah River Company, Savannah River Site, Bldg. 773-11A, Aiken, SC 29808-0001

54. L. Barrett, Office of Civilian Radioactive Waste Management, RW-232, U.S. Department of Energy, Washington, DC 20545

55. M. G. Bailey, Office of Nuclear Material Safety \& Safeguards, U.S. Nuclear Regulatory Commission, MS O6 G22, Washington, DC 20555

56. R. N. Blomquist, Argonne National Laboratory, 9700 S. Cass Ave., Argonne, IL 60439-4842

57. W. M. Blumberg, Houston Lighting \& Power Company, South Texas Project Electric Generating Station, P.O. Box 289, Wadsworth, TX 77483

58. J. K. Boshoven, General Atomics, 3550 General Atomics Court, San Diego, CA 92121-1194

59. R. L. Bowden, BNFL Engineering Group, Safety and Nuclear Technology Dept., Risley, Warrington, Cheshire WA3 6AS, United Kingdom

60. M. C. Brady, Sandia National Laboratories, 1261 Town Center Dr, Room 421A, Las Vegas, NV 89134

61. B. Briggs, EG\&G Idaho, Inc., P.O. Box 1625, Idaho Falls, ID 83415-3890

62. T. Brookmire, Virginia Power Co., P.O. Box 2666, Richmond, VA 23261

63. R. J. Cacciapouti, Yankee Atomic Electric Co., 580 Main St., Bolton, MA 01740 
64. D. E. Carlson, Nuclear Material Safety \& Safeguards, U.S. Nuclear Regulatory Commission, MS O6 G22, Washington, DC 20555

78. R. Carlson, Lawrence Livermore National Laboratory, P.O. Box 808, Livermore, CA 94550

79. G. Casher, VECTRA Technologies, Inc., 6203 San Ignacio Ave., Suite 100, San Jose, CA 95119

80. C. R. Chappell, U.S. Nuclear Regulatory Commission, Office of Nuclear Materials Safety and Safeguards, MS O6 F18, Washington, DC 20555

81. P. Childress, Babcock and Wilcox, 3315 Old Forest Road, P.O. Box 10935, Lynchburg, VA 245060935

82. Jor-Shan Choi, Lawrence Livermore National Laboratory, P.O. Box 808, L-634, Livermore, CA 94550

83. R. Coen, Siemens Nuclear Division, 2101 Horn Rapids Rd., P.O. Box 130, Richland, WA 99352

84. J. Conde, Consejo de Seguridad Nuclear, Justo Dorado, 11, 28040 Madrid, Spain

85. M. Conroy, Transportation Management Div., MS EM-261, U.S. Department of Energy, Washington, DC 20545

86. P. J. Cooper, Sandia National Laboratories, Division 6514, P.O. Box 5800, MS 1145, Albuquerque, NM 87185-5800

87. H. L. Dodds, University of Tennessee, Department of Nuclear Engineering, Knoxville, TN

88. T. W. Doering, Framatome Cogema Fuel Co., Suite 527, P.O. Box 98608, 101 Convention Center Drive, Las Vegas, NV 89109

89. R. Doman, Nuclear Packaging, Inc., 1010 S. 336th St., Suite 220, Federal Way, WA 98003

90. E. P. Easton, U.S. Nuclear Regulatory Commission, Office of Nuclear Materials Safety and Safeguards, MS O6 F18, Washington, DC 20555

91. P. Felsher, Safe Sites of Colorado, P.O. Box 464, Bldg. T886B, Golden, CO 80402-0464

92. I. Fergus, U.S. Department of Energy, MS EH-11, Washington, DC 20485

93. L. Fisher, Lawrence Livermore National Laboratory, P.O. Box 808, Livermore, CA 94550

94. A. Ford, Virginia Power Co., P.O. Box 2666, Richmond, VA 23261

95. R. A. Forster, Los Alamos National Laboratory, P.O. Box 1663, Los Alamos, NM 87545

96. R. S. Freeman, ABB Combustion Engineering, CEP 5318-GC28, 1000 Prospect Hill Road, Windsor, CT 06095

97. R. L. Frost, Westinghouse Savannah River Company, Savannah River Site, Bldg. 773-11A, Aiken, SC 29808-0001

98. H. Geiser, Wissenschaftlich-Technische Ingenieurberatung GmbH, P.O. Box 13 40, 52410 Jülich, Federal Republic of Germany

99. R. R. Getz, Duke Engineering \& Services, P.O. Box 1004, MS ST02A, Charlotte, NC 28201-1004

100. E. Greenspan, University of California, Berkeley, Department of Nuclear Engineering, Berkeley, CA 94720

101. G. Gualdrini, ENEA-TIB/FICS, C.R.E. "E. Clementel," Via Mazzini, 2, I-40139 Bologna, Italy

102. M. N. Haas, TESS, B\&W Fuel Co., MS 423, Suite 527, P.O. Box 98608, 101 Convention Center Drive, Las Vegas, NV 89109

103. D. Hanlon, 101/B21 Winfrith Technology Centre, Dorchester, Dorset, DT2 8DH, United Kingdom

104. K. J. Hardin, Office of Nuclear Material Safety \& Safeguards, U.S. Nuclear Regulatory Commission, MS TWFN 8 D14, Washington, DC 20555

105. L. A. Hassler, Babcock \& Wilcox, P.O. Box 10935, Lynchburg, VA 24506-0935

106. C. J. Haughney, U.S. Nuclear Regulatory Commission, Office of Nuclear Materials Safety and Safeguards, MS O6 F18, Washington, DC 20555

107. J. S. Hendricks, Los Alamos National Laboratory, P.O. Box 1663, Los Alamos, NM 87545

108. J. E. Hoogenboom, Delft University Technology, Mekelweg 15, 2629JB, Delft, The Netherlands 
109. U. Jenquin, Battelle Pacific Northwest Laboratory, P.O. Box 999, Richland, WA 99352

110. K. Jones, VECTRA Technologies, Inc., 6203 San Ignacio Ave., Suite 100, San Jose, CA 95119

111. S. Kapoor, Transportation \& Packaging Safety Div., MS EM-76, U.S. Department of Energy, Washington, DC 20545

112. N. Kent, Westinghouse Electric Corp., P.O. Drawer R, Columbia, SC 29250

113. K. D. Kimball, NISYS Corporation, 6055 Atlantic Boulevard, Suite G-2, Norcross, GA 30071

114. M. L. Klasky, Office of Nuclear Material Safety \& Safeguards, U.S. Nuclear Regulatory Commission, MS TWFN-8A-33, Washington, DC 20555

115. C. Kouts, Office of Civilian Radioactive Waste Management, RW-36, U.S. Department of Energy, Washington, DC 20545

116. H. Kühl, Wissenschaftlich-Technische Ingenieurberatung GmbH, P.O. Box 13 40, 52410 Jülich, Federal Republic of Germany

117. W. H. Lake, Office of Civilian Radioactive Waste Management, U.S. Department of Energy, RW-46, Washington, DC 20585

118. D. Lancaster, 2650 Park Tower Drive, Suite 800, Vienna, VA 22180

119. S. Larson, Battelle Pacific Northwest Labs, P.O. Box 999, MSIN K8-34, Richland, WA 99352

120. C. Lindner, Chem-Nuclear Systems, Inc., 140 Stoneridge Drive, Columbia, SC 29210

121. R. A. Little, Los Alamos National Laboratory, P.O. Box 1663, Los Alamos, NM 87545

122. E. Love, Battelle Pacific Northwest Labs, P.O. Box 999, MSIN K8-34, Richland, WA 99352

123. A. Luksic, Battelle Pacific Northwest Laboratory, P.O. Box 999, Richland, WA 99352

124. H. F. Lutz, Lawrence Livermore National Lab., Nuclear Systems Safety Program, P.O. Box 808, L197, Livermore, CA 94551

125. H. Manaktala, Manager, Engineered Barrier System, Center for Nuclear Waste Regulatory Analyses, Southwest Research Institute, 6220 Culebra Road, San Antonio, TX 78238-5166

126. M. Mason, Transnuclear, Inc., 2 Skyline Drive, Hawthorne, NY 10532

127. J. Massey, Sierra Nuclear Corporation, 5619 Scotts Valley Drive, Number 240, Scotts Valley, CA 95066

128. N. M. McLeod, E. R. Johnson Associates, 10461 White Granite Drive, Oakton, VA 22124

129. D. Mennerdahl, Starvägen 12, S-183 51 Täby, Sweden

130. A. Mobasheran, Roy F. Weston, Inc., 955 L'Enfant Plaza, SW, 8th Floor, Washington, DC 20024

131. R. Mosteller, Los Alamos National Laboratory, P.O. Box 1663, N-12, MS K551, Los Alamos, NM 87545

132. M. Mount, Lawrence Livermore National Lab., Nuclear Systems Safety Program, P.O. Box 808, L197, Livermore, CA 94551

133. P. K. Nair, Manager, Engineered Barrier System, Center for Nuclear Waste Regulatory Analyses, Southwest Research Institute, 6220 Culebra Road, San Antonio, TX 78238-5166

134. D. Napolitano, 655 Engineering Drive, Suite 200, Norcross, GA 30092

135. C. W. Nilsen, Office of Nuclear Regulatory Research, U.S. Nuclear Regulatory Commission, MS TWFN 9 F31, Washington, DC 20555

136. Y. Nomura, Department of Fuel Cycle Safety Research, Tokai Research Establishment, Japan Atomic Energy Research Institute, Tokai-Mura-Naka-Gun, Ibaraki-Ken, Japan

137. R. D. O'Dell, Los Alamos National Laboratory, P.O. Box 1663, Los Alamos, NM 87545

138. Office of the Deputy Assistant Manager for Energy, Research, and Development, U.S. Department of Energy, Oak Ridge Operations (DOE-ORO), P.O. Box 2001, Oak Ridge, TN 37831

139. Office of Scientific and Technical Information, P.O. Box 62, Oak Ridge, TN 37831

140. N. L. Osgood, Nuclear Material Safety \& Safeguards, U.S. Nuclear Regulatory Commission, MS 6 F18, Washington, DC 20555 
141. O. Ozer, Electric Power Research Institute, 3412 Hillview Ave., Palo Alto, CA 94304

142. P. Pacquin, General Nuclear Systems, Inc., 220 Stoneridge Dr., Columbia, SC 29210

143. T. Parish, Department of Nuclear Engineering, Texas A\&M University, College Station, TX 77843 3313

144. F. Prohammer, Argonne National Laboratory, 9700 S. Cass Ave., Bldg. 308, Argonne, IL 604394825

145. V. L. Putnam, Lockheed Martin Idaho Technologies, P.O. Box 1625, Idaho Falls, ID 83415-3458

146. M. Rahimi, 2650 Park Tower Drive, Suite 800, Vienna, VA 22180

147. E. Redmond, Holtec International, 100 Hano St., Suite 25, Allston, MA 02134

148. C. T. Rombough, CTR Technical Services, Inc., 5619 Misty Crest Dr., Arlington, TX 76017-4147

149. J. Rueth, Pacific Gas \& Electric Co., MS AlOK, P.O. Box 770000, San Francisco, CA 94177

150. E. Sartori, OECD/Nuclear Energy Agency, Le Seine-Saint Germain, 12, boulevard des Iles, F-92130 Issy-les-Moulineaux, France

151. H. Schweer, Bundesamt für Strahlenschutz, Albert-Schweitzer-Str. 18, 3320 Salzgitter 1, Federal Republic of Germany

152. M. K. Shaeffer, Lawrence Livermore National Laboratory, P.O. Box 808, L-197, Livermore, CA 94550

153. M. L. Smith, Virginia Power Co., 5000 Dominion Blvd., Glen Allen, VA 23060

154. K. B. Sorenson, Sandia National Laboratories, P.O. Box 5800, Div. 6643, MS 0716, Albuquerque, NM 87185-0716

155. F. C. Sturz, Office of Nuclear Material Safety \& Safeguards, U.S. Nuclear Regulatory Commission, MS O6 G22, Washington, DC 20555

156. J. Sun, Florida Power \& Light Co., P.O. Box 029100, Miami, FL 33102

157. T. Suto, Power Reactor and Nuclear Fuel Development Corp., 1-9-13, Akasaka, Minato-Ku, Tokyo, Japan

158. H. Taniuchi, Kobe Steel, Ltd., 3-1, Araicho-Shinhama, 2-Chome, Takasago, Hyogo, 676 Japan

159. J. E. Tanner, Westinghouse Idaho Nuclear Company, P.O. Box 4000, Idaho Falls, ID 83403

160. R. W. Tayloe, Jr., Battelle, 505 King Ave., Columbus, Ohio 43201

161. J. T. Taylor, WINCO (INEL), P.O. Box 4000, MS 3428, Idaho Falls, ID 83403

162. B. Thomas, VECTRA Technologies, Inc., 6203 San Ignacio Ave., Suite 100, San Jose, CA 95119

163. D. A. Thomas, Framatome Cogema Fuel Co., 101 Convention Center Drive, Suite 527, MS 423, Las Vegas, NV 89109

164. M. Thomas, Office of Nuclear Regulatory Research, U.S. Nuclear Regulatory Commission, MS TWFN 9 C24, Washington, DC 20555

165. J. R. Thornton, 2650 Park Tower Drive, Suite 800, Vienna, VA 22180

166. H. Toffer, Safe Sites of Colorado, P.O. Box 464, Bldg. T886B, Golden, C0 80402-0464

167. E. F. Trumble, Westinghouse Savannah River Company, Savannah River Site, Bldg. 773-11A, Aiken, SC 29808-0001

168. S. Turner, Holtec International, 230 Normandy Circle E, Palm Harbor, FL 34683

169. G. Walden, Duke Power Co., P.O. Box 33189, Charlotte, NC 28242

170. M. E. Wangler, U.S. Department of Energy, Transportation \& Packaging Safety Div., MS EM-76, Washington, DC 20585

171. W. Weber, Gesellschaft für Anlagen-und Reaktorsicherheit GmbH, Forschungsgelände, 85748 Garching, Munich, Federal Republic of Germany

172. F. G. Welfare, General Electric Co., Nuclear Fuel Manufacturing Dept., P.O. Box 780, Wilmington, NC 28402

173. R. M. Weller, U.S. Nuclear Regulatory Commission, MS TWFN 7 G6, Washington, DC 20555 
174. A. H. Wells, 2846 Peachtree Walk, Duluth, GA 30136

175. L. Wetzel, Babcock \& Wilcox/NNFD, P.O. Box 785, MC 46, Lynchburg, VA 24505-0785

176. W. Weyer, Wissenschaftlich-Technische Ingenieurberatung GmbH, P.O. Box 13 40, 52410 Jülich, Federal Republic of Germany

177. B. H. White, Office of Nuclear Material Safety \& Safeguards, U.S. Nuclear Regulatory Commission, MS O6 F18, Washington, DC 20555

178. J. Williams, Office of Civilian Radioactive Waste Management, U.S. Department of Energy, RW-46, Washington, DC 20545

179. M. L. Williams, Nuclear Science Center, Louisiana State University, Baton Rouge, LA 70803

180. C. K. Wilson, The Department of Transport, Zone 4/18, 76 Marsham St., London SW1P 4DR United Kingdom

181. R. E. Wilson, Safe Sites of Colorado, P.O. Box 464, Bldg. T886B, Golden, CO 80402-0464

182. C. J. Withee, Nuclear Material Safety \& Safeguards, U.S. Nuclear Regulatory Commission, MS O6 G22, Washington, DC 20555

183. R. Yang, Electric Power Research Institute, 3412 Hillview Ave., Palo Alto, CA 94304 


\begin{tabular}{|c|c|}
\hline $\begin{array}{l}\text { NRC FORM } 335 \\
\begin{array}{l}\text { (2-89) } \\
\text { NRCM 1102, } \\
\text { 3201, } 3202\end{array} \\
\text { BIBLIOGRAPHIC DATA SHEET } \\
\text { 2. TITLE AND SUBTITLE }\end{array}$ & $\begin{array}{l}\text { 1. REPORT NUMBER } \\
\text { (Assigned by NRC, Add Vol., Supp., Rev., } \\
\text { and Addendum Numbers, if any.) } \\
\text { NUREG/CR-6484 } \\
\text { ORNLTM-13277 }\end{array}$ \\
\hline \multirow[t]{3}{*}{$\begin{array}{l}\text { Guide to Verification and Validation of the SCALE-4 } \\
\text { Radiation Shielding Software }\end{array}$} & DATE REPORT PUBLISHED \\
\hline & \begin{tabular}{|c|r|} 
MONTH & YEAR \\
December & 1996 \\
\end{tabular} \\
\hline & $\begin{array}{l}\text { 4. FIN OR GRANT NUMBER } \\
\text { BOOO9 }\end{array}$ \\
\hline \multirow[t]{2}{*}{$\begin{array}{l}\text { 5. AUTHOR(S) } \\
\text { B. L. Broadhead, M. B. Emmett, J. S. Tang }\end{array}$} & $\begin{array}{l}\text { 6. TYPE OF REPORT } \\
\text { Technical }\end{array}$ \\
\hline & 7. PERIOD COVERED (Inclusive Dates) \\
\hline \multicolumn{2}{|c|}{$\begin{array}{l}\text { 8. PERFORMING ORGANIZATION - NAME AND ADDRESS (IF NRC, provide Division, Office or Region, U.S. Nuclear Regulatory Commission, and mailing address; if contractor, } \\
\text { provide name and mailing address.) }\end{array}$} \\
\hline $\begin{array}{l}\text { Oak Ridge National Laboratory } \\
\text { P.O. Box } 2008 \\
\text { Oak Ridge, TN } 37831-6370\end{array}$ & \\
\hline
\end{tabular}

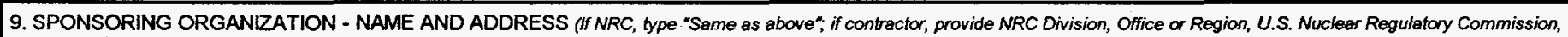
and mailing address.)

\section{Spent Fuel Project Office}

Office of Nuclear Material Safety and Safeguards

U.S. Nuclear Regulatory Commission

Washington, DC 20555-0001

10. SUPPLEMENTARY NOTES

\section{ABSTRACT (200 words or less)}

Whenever a decision is made to newly install the SCALE radiation shielding software on a computer system, the use should run a set of verification and validation (V\&V) test cases to demonstrate that the software is properly installeci and functioning correctly. This report is intended to serve as a guide for this V\&V in that it specifies test cases to run anci gives expected results. The report describes the V\&V that has been performed for the radiation shielding software in a version of SCALE-4.

This report provides documentation of sample problems which are recommended for use in the V\&V of the SCALE-4 system for all releases. The results reported in this document are from the SCALE-4.2P version which was run on an IBM RS/6000 workstation. These results verify that the SCALE-4 radiation shiclding software has been correctly installed and is functioning properly. A set of problems for use by other shielding codes (e.g., MCNP, ${ }^{2}$ TWOTRAN, ${ }^{3}$ MORSE ${ }^{4-6}$ ) performing similar V\&V are discussed.

A validation has been performed for XSDRNPM ${ }^{7}$ and MORSE-SGC ${ }^{6}$ utilizing SAS $1^{8}$ and SAS4 ${ }^{9}$ shiclding sequences and the SCALE 27-18 group (27N-18COUPLE) cross-scction library for typical nuclear reactor spent fuel sources and a variety of transport package geometries. The experimental models used for the validation were taken from two previous applications of the SAS1 and SAS4 methods.

12. KEY WOROSIOESCRIPTORS (List words or phrases that will assist researchers in locating the report)

SCALE, criticality safety, radiation shielding, verification, validation 